\title{
Analyzing environmental parameters for drying of neem and moringa leaves in solar greenhouse dryer regions of southern India
}

Rajesh K ( $\square$ thermorajesh12@gmail.com )

Arunai Engineering College

Shenbaga Vinayaga Moorthi N

Anna University Regional Campus, tirunelveli

Sivakumar E

Anna University Regional Campus ,Tirunelveli

\section{Original Article}

Keywords: Solar greenhouse dryer, Drying, Leaves drying , Neem leaves, moringa leaves

Posted Date: April 15th, 2020

DOI: https://doi.org/10.21203/rs.3.rs-21974/v1

License: (a) (1) This work is licensed under a Creative Commons Attribution 4.0 International License. Read Full License 


\section{Abstract}

The green foliage of plants plays a vital role in the Traditional Medical System(TMS). Especially neem and moringa contains rich nutrients and hence used for medicinal purpose, preserving and drying of these leaves are found to be most important. Using a solar greenhouse dryer(GHD) for this purpose reduces the cost of energy and maintains herbal's own multifarious spectrum of constituent substances.Drying of these herbals in solar greenhouse dryer depends on the duration of sunshine hours in a particular day, atmospheric pressure, air temperature, relative humidity, wind speed, rainfall, turbidity parameters and transmission coefficients. In the above parameters, finding the longest duration sun shine hours and the best intensity rate of the sunshine are considered to be important to get better performance from the dryer. This communication throws light on the (1) Best time to start the drying process in a particular day ,month and year in GPS co-ordinates $\left(12.2253^{\circ} \mathrm{N}\right.$, $79.0747^{\circ} \mathrm{E}$ ) of Tiruvannamalai, Tamilnadu (2) Fabrication of the experimental setup of solar greenhouse dryer (3) Conducting the test for reduction of moisture up to safe limit of moisture content (4) Experimental results are to be validated with the theoretical results.

\section{Introduction}

Neem (called as Vembu in the regions of southern India)(Azadirachta indica) is the most valuable and available medicinal plant. It's mostly found in the Indian subcontinent. Due to its adorable properties and less side effects improves its therapeutic roles in disease managements. With antimicrobial effects of neem leaf (Azadirachta indica A. Juss) extract decreases the salivary bacterial count without any side effects (Pai et al., 2004). Chloroform extract (Lekshmi et al., 2012)from neem have a strong activity against the Streptococcus salivarius. Neem leaves considered (Airaodion et al., 2019)to have a powerful anti-bacterial, anti-inflammatory, antifungal, antiseptic effects, these makes the consumption of neem extract in any form (gel, powder and paste etc) treats maximum numbers of diseases(leprosy, biliousness, eye-related problems, intestinal worms, anorexia, skin problems (skin ulcers)).It has been broadly utilized in(Alzohairy, 2016) Chinese, Ayurvedic, and Unani prescriptions worldwide particularly in Indian subcontinent in the treatment and counteractive action of different ailments. Neem leaves have vitro antiviral activity (Parida et al., 2002) provides inhibition to control the replications of Dengue virus type-2.

Moringa (Called as murungai in the region of southern India) (Moringa Oleifera) is an indigenous plant native to the countries like India, Afghanistan, Bangladesh, and Pakistan. These leaves are rich in protein, iron, vitamin $\mathrm{C}$ and carotenoids (Thurber \& Fahey, n.d.). Moringa leaves place major role in the food industry (Folashade et al., 2017) and the medical industry(Margarita et al., 2018) due to its extended nutrition value. The pharmacological properties of the moringa leave include hepatoprotective, anti-fungal, anti-ulcer, anti-bacterial etc. The finegrained powder of dried moringa leaves has its peculiar importance in Traditional Medical System(TMS). Moringa leaf powder is used to improve the (Boateng et al., 2018) blood retinol concentrations and taking fresh or dried moringa leaves satisfies the nutrients needs of children(aged between 1-2 years). Table.1 having the details about the nutritive value of moringa oleifera(Sodamade et al., 2013).

Moringa and neem leaves are used as a powder(Peddi, 2018)(Boateng et al., 2018)(Lekshmi et al., 2012) in the applications of medical and food processing industries. Before we start a process of making powder from those leaves, we need to eliminate the moisture content from it, obviously this will reduce the volume and weight of the leaves. The drying process removes that moisture content from the leaves and save the product from the 
spoilage. Demand for the dried neem and moringa leaves in the medicinal and agriculture department is considerably increased worldwide. In the starting stage of the solar dryers, efficiency is low and drying time is high. The area of drying determines its type as open sun drying or enclosed sun drying. Open sun drying requires large open space area, and fully depends on the availability of sunshine and drying leads to contamination of foreign material such as specks of dust, litter, time-consuming and is exposed to birds. The technical development of solar dryer can proceed in two directions, first one involves simple, low power, short life, and comparatively low-efficiency drying system and later one have high efficiency rate and drying system with extended life. Three types of drying methods are in practices, which are (Prakash \& Kumar, 2014) direct, indirect and mixed -mode. The energy requirement is determined by the initial and final moisture content of the product. Dryers (Prakash \& Kumar, 2014) based on each product has different drying rates ,allowable rates of moisture content and maximum allowable temperature.

\section{Classification Of Dryers Used In Leaves Drying}

Dried Stevia (Rebaudiana Bertoni) leaves contain an enormous amount of sweetening content (Castillo et al., 2018). Experimental investigation of the dehydration process of these leaves used direct (cabinet) (natural and forced convection) and indirect solar drying(tunnel type)methods. The indirect drying has high feasibility, better performance than the direct drying. Considering colorimetric analysis mainly depends on the temperature and it is the most important property that affects the tone. Mesh shadow cover integration with the dryer increases the convection yield and reduction in discoloration effects. The moisture content of Valeriana Jatamansi (Bhardwaj et al., 2019) leaves reduced from the initial value $89 \%$ to $9 \%$ in the shade dryer and solar dryer integrated with heat storage material(forced convection solar dryer)

Drying of Brachypodium retusum investigated by (Vidaller, 2018), revealed the colonization patterns of the brachypodium retusum leaves. Investigation about kale(Brassica oleracea L. var. acephala) leaves drying by (Korus, 2011) obtained dried leaves by freeze and air drying method and include the process of maximizing the antioxidants and maintain the value of high vitamin $\mathrm{c}$ in raw kale leaves.

(Ziegler , 2019) used the batch-type grate drying and (Amer et al., 2018) used integrated hybrid solar dryer for chamomile flowers drying with energy-saving and cost-reducing by combined heat and power generation methods at same time. Moisture extraction in plants determined on air-side and product-side balances of mass. Java tea (Orthosiphon aristatus) and Sabah snake grass (Clinacanthus nutans Lindau) (Tham et al., 2017) were dried in a solar greenhouse dryer integrated with a heat pump. The heat pump places a vital role in the reduction of relative humidity by $10-15 \%$ and also minimizes the non-uniformity in relative humidity and drying temperature. (Selin et al., 2018) Olea europaea leaf dried in microwave drying method (Hossain et al., 2010) thyme, rosemary, marjoram ,oregano, sage and basil dried in air-, freeze- and vacuum oven-drying.

Drying investigation of Clinacanthus nutans leaves in heat pump assisted solar dryer concentrated on the method to maximize the extraction rate of orientin and vitexin. ( $\mathrm{Ng}$ et al., 2017). They have tested the sample under the sun drying and heat pump assisted solar drying methods and under heat pump assisted solar dryer got the result as $31.14 \%$ and in sun-drying $35.84 \%$ dry-basis was the result. Maintained the temperature as $28.1^{\circ} \mathrm{C}$ to $46.2^{\circ} \mathrm{C}$ in sun drying and $28.7^{\circ} \mathrm{C}$ to $48.0^{\circ} \mathrm{C}$ in heat pump assisted solar drying. 
(Rajesh, K, Karuppasazmy, 2016) were reported that the parameters considered for drying of leaves like adhatoda, Thuthuvalai, podudhalai, pallamaram (Origin-India (Tamilnadu)) in solar shade greenhouse dryer are solar intensity, mass flow rate, and two different areas slope angles (CASE-I $2 \mathrm{~m}^{2}$ and CASE-II $0.5 \mathrm{~m}^{2}$ ). Experimental results provided $19 \%$ more amount of heat gained than the theoretical value. The main consideration for using a greenhouse dryer for drying reduces the open sun drying shortcomings like dust, contaminations, the problem with the product color.

Mate leaves (Ilex paraguariensis) dried in the thin-layer conveyor-belt dryer (llex paraguariensis) (Taylor et al., 2014). The speed of the belt was manually adjustable and temperature inside the dryer range from 55 to $130^{\circ} \mathrm{C}$.

(Premi et al., 2010) determined that the experimental setup of the electric convective dryer for moringa oleifera leaves drying (Origin-South Africa, Asia). Maintaining the air velocity at $0.5 \mathrm{~m} / \mathrm{s}$ reduced the moisture content from $3 \%(\mathrm{db})$ to $74 \%$. Experimental studies have been found that $60^{\circ} \mathrm{C}$ is the optimum one in terms of energy efficiency. Sample dried at $60^{\circ} \mathrm{C}$ is found better for good color as compared to other samples dried temperatures. Moisture content in the final state of the product was $3 \%(\mathrm{db})$. Dimensions of dryer used was $420 \mathrm{~mm} \times 320 \mathrm{~mm}$ $\times 400 \mathrm{~mm}$.

Jew's mallow, spearmint and parsley has been a part of a sample in experimental work by (Fatouh et al., 2006). Heat pump assisted dryer is used to dry these herbs. Dryer with $28 \mathrm{~kg} / \mathrm{m}^{2}$ load sample gives the best result at temperature $55^{\circ} \mathrm{C}$ and velocity $2.7 \mathrm{~m} / \mathrm{s}$. After $2,2.5,5.5,6.5,7.5$ hours the respective final moisture content of $24.2 \%, 18.8 \%, 4.7 \%, 2.3 \%$ and $1.7 \%$ were attainted for the sample loaded surfaces 3.5, 7, 14, 21 and $28 \mathrm{~kg} / \mathrm{m} 2 \mathrm{in}$ the heat pump assisted dryer.

(Demir et al., 2004) used more than one dryer to determine the significant change in the bay leaves( OriginMediterranean region and Asia Minor). They found variations inside the experimental setup by make a change in temperature maintained inside the dryer. The moisture content of the bay leaves down to $10 \%(\mathrm{wb})$ at $60^{\circ} \mathrm{C}$ can shorten the drying time about 80-140 times. They concluded that the page model was considered as a good model for bay leaves drying. They consider only the falling rate of the drying period because the initial moisture content is low. There is no significant change in bay leaves while dried at 60 and $40^{\circ} \mathrm{C}$.

(Shaw et al., 2006)determined that the drying coriander foliage (origin-Southern Europe and Northern Africa to southwestern Asia) in the microwave dryer was faster than drying in the convective dryer. There was a significant change in brightness ( $L$ value) when compared with the samples dried in a microwave and convective drying, convective dryer produced higher $L$ value. Preeminent drying rate and product quality is based on the color of the dried sample. In microwave dryer the range of $40^{\circ} \mathrm{C}-60^{\circ} \mathrm{C}$ is found to be best for drying with minimal loss of quality in drying herbs.

(Bensebia \& Allia, 2015)explained five models to evaluate the temperature of the oven for proper drying of rosemary leaves (origin-Mediterranean region). They found that the drying temperature affects the drying kinetics majorly they proved the page model was a better prediction model for oven drying. The drying was carried out in a convection oven $\left(40,50\right.$ and $\left.60^{\circ} \mathrm{C}\right)$ and at ambient air drying $\left(21^{\circ} \mathrm{C}\right)$. The calculated values of apparent moisture diffusivity were varied from $2.1 \times 10-13 \mathrm{~m}^{2} / \mathrm{s}$ to $9.4 \times 10-12 \mathrm{~m}^{2} / \mathrm{s}$. The increase in temperature increases the apparent diffusivity also. 
(Arabhosseini et al., 2009) They took independent variables such as temperature, RH, and material (Artemisia dracunculus $L$ ) as an experimental variable for drying of Artemisia dracunculus L.(origin-Eurasia and North America,) (tarragon leaves) in Lab dryer. They have chosen the page equation instead of a diffusion equation to find the dependency between the parameters temperature and (Relative Humidity)RH value of the material. The drying time is reduced during the process of increasing the drying temperature. Various drying equations are used to calculate the energy consumption and drying time

(Janjai \& Tung, 2005)they found that south-facing collector in Thailand have received higher radiation than north facing collector for Rosella flower(origin- West africa, Asian)and lemon-grasses drying. Four tests have been carried out for the rosella flower and two tests been carried out for lemon-grasses (origin-African, Australian)in the bin-type dryer. They used final moistures of $6 \%(\mathrm{wb})$ for lemon-grasses and $16 \%(\mathrm{wb})$ for rosella flowers $103^{\circ} \mathrm{C}$ for $24 \mathrm{hrs}$ been followed for drying.

(Kaya \& Aydin, 2009) experimentally proved that the drying of mint (origin-Europe, Africa, Asia and Australia)and nettle(origin- North America Europe, Asia, Northern africa) in the experimental setup which contains the drying channel, air blowing channel. When the continuous increases in both temperature and constant equilibrium relative humidity will leads to decrease the equilibrium moisture content. A continuing experimental test with invariable temperature, invariable equilibrium relative humidity, increases the equilibrium moisture content. They concluded that the increase in the drying air temperature and velocity will reduce the overall time taken for drying. At velocity $0.6 \mathrm{~m} / \mathrm{s}$, time required for drying is about to $260 \mathrm{~min}$ and the sane is decreased from 280 that is obtained at $0.2 \mathrm{~m} / \mathrm{s}$.

(Doymaz et al., 2006)they determined that within the temperature change the diffusivity values changed from 9.0 *10 -10 to $2.337 * 10-9$ m2/s $6.693 * 10-10$ to $1.434 * 10-9$ m2/s for parsley (origin-Mediterranean region) and dill leaves(origin-unknown). Among all models, the Midilli and Kucuk model are considered as a best model to execute. $\left(50,60\right.$ and $\left.70^{\circ} \mathrm{C}\right)$ these three air temperatures were chosen for drying, constant material weight also maintained. $60^{\circ} \mathrm{C}$ was the optimum temperature for leaves drying

(Mohamed et al., 2005)they had selected indirect forced convection solar dryer for drying Citrus aurantium leaves (origin- southeast Asia). They concluded that temperature was the main factor that influences the drying kinetic among all the thin layer model. The initial moisture content of the Citrus aurantium leaves ranged from the percentage of 0.975 to $1.584 \mathrm{~kg}$ water/ $\mathrm{kg}$ dry matter and after it was reduced, which varies from 0.1576 to $0.2475 \mathrm{~kg}$ water per $\mathrm{kg}$ dry matter. They found that the Midilli-Kucuk drying model was the best one for Citrus aurantium leaves drying curves.

(Hassanain \& others, 2011) they introduced that Unglazed perforated passive solar dryer for sage leaves(originMediterranean region) drying. Extracting essential oil was the major condition for drying. They used UV protected polyethylene, to build the greenhouse dryer. Three types of drying conditions were followed those are (i).Fully direct sun-rays.(ii)half direct sun rays and half shadow (iii). $0 \%$ sun rays achieved through barn dryer .Temperature and relative humidity considered as important parameters in this study. Table.2 having a comparative analysis of various leaves drying and methods used. (Gulia et al., 2010)determined that aloe vera(origin-Arabian Peninsula ) dried in hot air oven dryer, the temperature increased from 50 to $80^{\circ} \mathrm{C}$, the humidity content decreased from 10.6 to 1.7 . The temperatures $50,60,70$ and $80^{\circ} \mathrm{C}$ were maintained to improve the $\mathrm{pH}$ level of the drying sample. 


\subsection{Why greenhouse dryer for leaves drying?}

From the above mentioned studies leaves which is used in medicinal purpose collected and dried. As we discussed earlier due to rain ,contamination and insects, etc.(Taylor et al., 2013) can induce a sustainable loss in open sun drying. Design of the greenhouse dryer defines the performance of the setup. Greenhouse dryer with natural convection method is suitable for the products having low moisture content(Singh et al., 2016). Clean energy utilization of the greenhouse dryer extend it usage in all domain(Kant et al., 2016). Leaves dried in greenhouse dryer having superior quality and color when compared to open sun drying(Prakash \& Kumar, 2014). Drying of neem and moringa leaves takes place in solar greenhouse dryer with natural convection method.

\section{Experimental Setup And Procedure}

\subsection{Dryer setup location details}

Medium scale experimental solar greenhouse dryer setup was located in the coordinates $\left(12.2253^{\circ} \mathrm{N}, 7^{9} .0747^{\circ}\right.$ E) of Tiruvannamalai, Tamilnadu, India. The climate of this co ordinates is Tropical. In this (GHD) the structure is fully covered by polyethylene made up of wooden material. Polyethylene cover is used to trap the solar radiation. Greenhouse dryer maintains the temperature greater than the surrounding temperature it helps to dry the herbals safely and effectively $(1.5 \mathrm{~m} \times 1.0 \mathrm{~m} \times 1.07 \mathrm{~m})$ Length*Width*Height). Perforated stable tray with the size of 15 mesh tray with a dimension $(1.5 \mathrm{~m} \times 1.0 \mathrm{~m})$, The Slope angle $(\beta)$ of the setup is $20^{\circ}$, and the thickness of $\mathrm{GH}$ cover(t) is $2 \mathrm{~mm}$. Figure 1a, 1b, 1c, 1d,1e shows grenhouse dryer 3D view, tray structure, experimental view, tray structure (photograhic view ), photographic view of the experimental dryer setup respectively.

\subsection{Dryer sample collection}

Dryer samples include neem and moringa leaves. These samples are collected in the tropical region of Tamilnadu, Tiruvannamalai. The stem and flowers of the samples are removed. Leaves are only considered as a dryer sample based on the design constraints, the developed solar collector can handle up to a mass of 500 grams of neem and moringa leaves, owing to design constraints. The drying process of those herbals fully depends on solar energy . Inside this greenhouse dryer, solar energy is trapped and it is been circulated inside the dryer setup by convection process of the air molecules. So moderate temperature is maintained inside the greenhouse dryer setup for drying herbals.

\subsection{Instruments/Equipment's used in experimental work.}

Weighing machine with high precision is used in this experiment to measure the high precision values. High precision weight measuring machine with the model name of Kea-20 kgm made by atlas was used for weighing purposes with accuracy $2 \mathrm{~g}$. The solar intensity was measured with the help of a Pyranometer (Lux meter) (model name UNI-T UT383) made by AmiciSense with accuracy $\pm 0.5 \mathrm{~W} / \mathrm{m}^{2}$. Temperature and humidity were measured by thermo-hygrometer manufactured by HTC Instrument with model name 103-CTH and having error analysis of $\pm 0.5^{\circ} \mathrm{C}, \pm 3 \%$. Wind speed was measured by amiciSense GM816 Pocket LCD digital anemometer air wind speed gauge. Table 3 includes the actual images and specifications of the instruments used in the present work.

\subsection{Error analysis}


During experimentation, the event of blunder was because of the following (Karthickeyan, 2019) conditions like ill-advised alignment of equipment, working condition, ecological condition, perception, exactness, and accuracy of equipments and so on. Vulnerability examination demonstrated by accuracy of measurements.

The temperature of the room air considered as the most sensitive parameter of greenhouse dryer(Chauhan \& Kumar, 2016)(Prakash \& Kumar, 2014). Need to combine the internal uncertainty percentage with external uncertainty percentage. Therefore, uncertainty of present equipment used was calculated as \pm 19.57 , in which internal was \pm 19.53 and external was \pm 0.4 .

\subsection{Finding a suitable environmental parameter for drying}

As we said earlier the parameters considered to get better drying coefficient for the study are Duration of sunshine hours in a particular day, Atmospheric pressure, Air temperature, Relative humidity, Wind speed, Rainfall.

The duration of the sunshine hours depends on solar radiant exposure. Fig.2, shows the mean monthly solar radiant exposure in Tiruvannamalai, according to the survey by Indian Meteorological Department during the year 2009. Tiruvannamalai is the place which is been selected as a location to set up a solar greenhouse dryer.

Considering March, April, May those three months having the highest solar radiant exposure. April month is chosen as the best month to get the highest drying rate in solar greenhouse dryer setup. Fig.3, includes the details of the average radiant exposure in the month of April. Once we chose April month for testing the samples for drying after need to find out which are the days in the months have the highest mean radiant exposure. This plot explained that merely 20 days in April month have a highest radiant exposure.

Considering the humidity variations in April month is well taken to provide a way to find the acurate days to get better temperature deviations. April month gives better result than the other months. In the month of April merely more than 20 days having considerably low humidity. Fig.4, showing this details on humidity change in April month and this is a mean value of whole single day. In this plot starting days of the month having high humidity but the countinuos 20 days having constant low humidity percentage, this is the better condition to improve the drying rate of the dryer in a particular time period. This mean atmospheric humidity calculated during 9 am to 12 am.

The humidity is indirect proportional to the temperature change. Decrease in humidity will affect the temperature value, so it automatically increases. Starting days ( $1^{\text {st }}$ day to $20^{\text {th }}$ day) of the month having low humidity so the temperature value will be high. Fig.5, having the relationship between the temperature and humidity dataplot.

From the above data plots (Fig.5), increase the probability of choosing April is the, moderate month to carry over the drying test in Tiruvannamalai.

\section{Drying Methodology}


In this solar greenhouse dryer, the polyethylene cover is used as the roof top material to close the dryer setup, and is shown in Fig.1. The figures 6, 7, 8 and 9 gives a view on the drying process of moringa and neem leaves in solar greenhouse dryer. This images showcaes the quality of the products in pre and post drying process this quality obtained by maintaining the allowable temperature $\left(35\right.$ to $\left.40^{\circ} \mathrm{C}\right)$ inside the dryer will retain the minerals and proteins in the leaves. East-west orientation is followed in the greenhouse dryer setup. Evolving the best slope angle place major role in the process of getting moderate solar irradiance inside the solar greenhouse dryer. Table 3 and 4 elaborated the information about the solar irradiance variations with respect to slope angle.

The herbal sample was kept in the tray situated inside the greenhouse dryer. After three hours interval the observation was taken for the dried leaves inside the dryer. Rate of moisture removal calculated from the difference of mass of leaves between two succeeding times 9 am to 12 am, 12 am to 3 pm, and 3 pm to 6 pm. So as to get exact results, the experimentation system was repeated multiple times for each test naturally collected fresh neem and moringa leaves samples of a similar size (i.e., neem leaves with length $=600 \mathrm{~mm}$ and thickness $=0.01 \mathrm{~mm}$ and moringa leaves with length = $250 \mathrm{~mm}$ and thickness = $0.01 \mathrm{~mm}$ ) on back to back days at the equivalent timing. The underlying mass of leaves sample for each experiment of drying was kept steady (i.e., $200 \mathrm{~g}$ ). The average convective heat transfer co-efficient for the neem and moringa leaves during drying is $1.41\left(\mathrm{~W} / \mathrm{m}^{2}{ }^{\circ} \mathrm{C}\right)$ for the values $\mathrm{C}(0.924)$ and $\mathrm{n}(0.154)$ and the average value of the Nusselt number expression is 0.918 and 0.148 for the constant and exponent repectively.

\section{A. Specification of experimental set up}

Length of the $\mathrm{GH}$ dryer $(\mathrm{L})=1.5 \mathrm{~m}$

Wide of the GH dryer $(\mathrm{W})=1.0 \mathrm{~m}$

Height of the GH dryer $(H)=1.07 m$

Slope angle $(\beta) \quad=20^{\circ}$

Thickness of $\mathrm{GH}$ cover $(\mathrm{t})=0.02 \mathrm{~m}$

Cover = Polyethylene sheet

\section{B. Assumptions for calculation (greenhouse dryer)}

Outside ambient air temperature $\left(\mathrm{T}_{\mathrm{ao}}\right) \quad=308 \mathrm{~K}$

Inside ambient air temperature $\left(\mathrm{T}_{\mathrm{ai}}\right) \quad=310 \mathrm{~K}$

Cover temperature $\left(T_{c}\right) \quad=313 \mathrm{~K}$

Solar Intensity (I) = $\quad=5520 \mathrm{~W} / \mathrm{m}^{2} \mathrm{~K} /$ day

Specific heat of air $\left(C_{p}\right) \quad=1.005 \mathrm{~kJ} / \mathrm{kg} / \mathrm{s}$

Wind velocity $\left(\mathrm{V}_{\mathrm{w}}\right) \quad=1 \mathrm{~m} / \mathrm{sec}$ 
Thermal conductivity of air $\left(\mathrm{k}_{\mathrm{air}}\right)$

Thermal conductivity of cover $\left(\mathrm{k}_{\mathrm{c}}\right)$

Emissivity of cover $\left(\varepsilon_{\mathrm{c}}\right)$

Emissivity of the product(neem and moringa $)=\sim 0.983 \pm 0.008$ and $0.985 \pm 0.006$
$=0.02826 \mathrm{~W} / \mathrm{mK}$

$=0.12 \mathrm{~W} / \mathrm{mK}$

$=\sim 0.5$

\section{C.Characteristics of drying product (leaves)}

Typical moisture content

Optimum moisture content

Maximum allowable temperature

The above specifications are considered during the process of greenhouse drying process parameter calculations. The environmental parameter values are fully describing on the specifications of the dryer setup. These specified values being considered in the month of April. Because in the April month, environmental parameters are merely suitable for leaves drying. The temperature consistency reduces the fungi and other microbial formation in the raw leaves. Raw leaves contain a large amount of moisture in it.

\subsection{Relationship between the environmental parameters with respect to time}

The better performance in solar greenhouse dryer depends on the environmental parameters, includes the particular testing area's temperature, humidity, pressure and wind speed. All these parametric values depend on the time duration of the sunlight, and standard time in that particular area. This clock time is considered as the major criteria to obtain better result in dryer and Fig.10, includes the relationship between the average values of temperature,humidity, pressure,wind speed in Tiruvannamalai during April month from 9 am to 12 am. Fig.11 includes the details over the Relationship between the average Values of temperature, humidity, pressure,wind speed in Tiruvannamalai during April month from 3 pm to $6 \mathrm{pm}$.

From Fig.10, it shows that the average value of temperature, pressure, wind speed and humidity at Tiruvannamalai during April month from 9 am to 12 am are as follows,

Average temperature $\left({ }^{\circ} \mathrm{C}\right) \quad=26.54^{\circ} \mathrm{C}$

Average pressure value $(\mathrm{hPa})=1010 \mathrm{hPa}$

Average wind speed $\left(\mathrm{kmh}^{-1}\right) \quad=11.50$

Average humidity $(\%) \quad=42.4 \%$.

From the Fig.11, it shows that the average value of temperature, pressure, wind speed and humidity at Tiruvannamalai during april month from 12 am to $3 \mathrm{pm}$ are as follows,

Average temperature $\left({ }^{\circ} \mathrm{C}\right) \quad=28^{\circ} \mathrm{C}$ 
Average pressure value $(\mathrm{hPa})=1010 \mathrm{hPa}$

Average wind speed $\left(\mathrm{kmh}^{-1}\right) \quad=10.22$

Average humidity $(\%) \quad=40.9 \%$.

From Fig.12, it shows that the average value of temperature, pressure, wind speed and Humidity at Tiruvannamalai during April month from 12 am to 3 pm are as follows,

Average temperature $\left({ }^{\circ} \mathrm{C}\right) \quad=38^{\circ} \mathrm{C}$

Average pressure value $(\mathrm{hPa})=1032.14 \mathrm{hPa}$

Average wind speed $\left(\mathrm{kmh}^{-1}\right) \quad=12.50$

Average humidity (\%) $\quad=36.5 \%$.

From the figures 10,11,12, it reveals that the clock hours 12 am to $3 \mathrm{pm}$ have the highest temperature and lowest humidity. The test results are taken during in this hour and in the month of April at Tiruvannamalai. The dryer test is conducted in this period and the temperature value was found to be high.

\subsection{Mathematical modeling of greenhouse dryer}

\subsubsection{Determination of moisture removal rate}

The moisture removal rate is calculated by,

$M R=\frac{m_{i}-m_{f}}{t_{d}} \quad(\mathrm{~kg} / \mathrm{s})$

where ,

$\mathrm{m}_{\mathrm{i}} \quad$ Mass of sample before drying, $\mathrm{kg}$

$\mathrm{m}_{\mathrm{f}} \quad$ Mass of sample after drying, $\mathrm{kg}$

$t_{d} \quad$ The drying duration time, $s$

A. Moisture loss

The moisture loss is given by

$M L=m_{i}-m_{f}(\mathrm{~kg})$

where,

$\mathrm{m}_{\mathrm{i}} \quad$ Mass of sample before drying, $\mathrm{kg}$

$m_{f} \quad$ Mass of sample after drying, $\mathrm{kg}$ 
B. Radiation heat transfer coefficient between the product to cover (Norton, 2014) $\left(h_{r, p-}\right)$

$$
h_{r, p-c}=\varepsilon_{p} \sigma\left(T_{p}^{2}+T_{c}^{2}\right)\left(T_{p}+T_{c}\right)
$$

where,

$\varepsilon_{\mathrm{p}} \quad$ Emissivity of the product

$\mathrm{T}_{\mathrm{p}} \quad$ Product temperature, $\mathrm{K}$

C. Convective Heat Transfer Coefficient (Rajesh, K, Karuppasamy, 2016)( $h$ d

$$
h_{c}=\left(\frac{N u \times k_{a}}{D_{h}}\right)
$$

where,

$\mathrm{Nu} \quad$ Nusselt number

$\mathrm{Nu}=\mathrm{h}_{\mathrm{cw}} \mathrm{L}_{\mathrm{c}} / \mathrm{K}_{\mathrm{v}}$

$\mathrm{k}_{\mathrm{a}} \quad$ Thermal conductivity of air, $\mathrm{W} / \mathrm{mK}$

D. Convective heat transfer coefficient between cover to ambient(Norton, 2014) $\left(h_{w}\right)$

$$
h_{w}=5.7+3.8 V_{w} \quad\left(\mathrm{~W} / \mathrm{m}^{2} \mathrm{~K}\right)
$$

E. Overall heat loss co-efficient from the cover (Norton, 2014) $\left(U_{c}\right)$

$$
U_{c}=\frac{k_{c}}{\delta_{c}}\left(\mathrm{~W} / \mathrm{m}^{2} \mathrm{~K}\right)
$$

where,

$\mathrm{k}_{\mathrm{c}} \quad$ Thermal conductivity of the cover, $\mathrm{W} / \mathrm{mK}$

$\delta_{c} \quad$ Cover thickness, $m$

E. Relative humidity $\left[H_{R}\right]$

$H_{R}=100$

where

$\mathrm{P}_{\mathrm{S}} \quad$ vapor pressure of water, $\mathrm{hPa}$ 


\section{F. Absolute humidity $[H]$}

$\mathrm{H}=\mathrm{m}_{\mathrm{w}} / \mathrm{V}_{\mathrm{a}}$

where,

$\mathrm{M}_{\mathrm{w}} \quad$ mass of the water vapor

$\mathrm{V}_{\mathrm{a}} \quad$ volume of air

The specification of the experimental test setup, assumptions for calculation using above equations and the characteristics of drying products are defined already in this work. This values are referred with standard journals.

\section{Result And Analysis}

\subsection{Samples heat gain ratio}

The dryer analysis of solar greenhouse dryer depends on the slope angle decides the heat gain for the sample which is being used inside the solar greenhouse dryer. Table 4 and Table 5 have the data regarding moringa and neem leaves heat gain ratio respectively. Finding best slope angle for the dryer setup includes the continuous angle change in slope angle during the dryer test and for the average heat transfer co-efficient $1.41\left(\mathrm{~W} / \mathrm{m} 2{ }^{\circ} \mathrm{C}\right)$. Samples heat gain values for respective slope angle with heat gain is tabulated and plotted with graph in Table 4 and Fig. 13. From figures 13 and 14, the heat gain in both the samples (neem and moringa ) are found to be high in during 12 am to $3 \mathrm{pm}$ with dryer assisted slope angle at $20^{\circ}$

Similarly solar green house dryer has been designed to dry (Rajesh, K, Karuppasazmy, 2016) adhatoda, thuthuvalai, podudhalai, pallamaram leaves with improved heat gain was calculated as (182.68W).

\subsection{Moisture removal rate in samples:}

Main purpose of this solar greenhouse dryer is to remove moisture content in neem and moringa leaves with maximum efficiency. By improving the efficiency of the dryer, samples are spread in the form of thin layer this leads to equal distribution of solar irradiance inside the greenhouse dryer. With the previous discussions April month in Tiruvannamalai is best month to get the better drying result in dryer and also 12 am to 3 pm is the best time to get maximum temperature and maximum moisture removal rate (\%). So the test was taken place in April month. Table 7, describes the moisture removal rate in moringa leaves from 9 am to 12 am, 12 am to 3 pm and $3 \mathrm{pm}$ to $6 \mathrm{pm}$. From this data the moisture removal rate (\%) during $12 \mathrm{am}$ to $3 \mathrm{pm}$ is found to be high. This is because during that time the temperature is high and humidity is low this leads to better moisture removal rate. Table 6 describes the moisture removal rate in neem leaves during the times 9 am to 12 am,12 am to 3 pm and $3 \mathrm{pm}$ to $6 \mathrm{pm}$. From this data table,12 am to $3 \mathrm{pm}$ is the best time to dry a sample with high moisture removal rate (\%).Similarly lemon grass(Janjai \& Tung, 2005) , Jatamansi (Bhardwaj et al., 2019) leaves and Clinacanthus nutans leaves ( $\mathrm{Ng}$ et al., 2017) has been dried using bin type drying ,mesh shadow drying and sun drying 
respectively to reduce the moisture content and the moisture removal rate was reported as $89 \%$ to $9 \%, 35.84 \%$ $(\mathrm{db}), 6 \%(\mathrm{wb})$ respectively.

As we discussed earlier among all the months considered, April month is the suitable month to dry the leaves like neem and moringa and this should be take place in 12 am to $3 \mathrm{pm}$. So far the main theme of this

communication is said deeply through the previous data tables and plots. From those data tables and data plots we understood that in Thiruvannamalai which month has a highest radiant exposure, highest temperature,lowest humidity and which duration of sunshine hour will give better result for dryer setup.

From Fig.15 and Fig.16, is known about the Moisture Removal Rate (\%) for 6 samples in 6 days with same quantity. The samples are tested in April month at Tiruvannamalai in different time slots like 9 am to 12 am ,12 am to $3 \mathrm{pm}$ and $3 \mathrm{pm}$ to $6 \mathrm{pm}$. Rate of moisture removal calculated from the difference of mass of leaves between two succeeding times 9 am to 12 am, 12 am to 3 pm, and 3pm to $6 \mathrm{pm}$. This test was conducted for both neem leaves and moringa leaves sepearately. From that data plot, the highest moisture removal rate is obtained during $12 \mathrm{am}$ to $3 \mathrm{pm}$ for both neem and moringa leaves. From both data table and plot we understood that comparativly noon hours(12 am to $3 \mathrm{pm}$ ) have highest moisture removal rate for neem (82.93\%) and moringa leaves (83.43\%). But during forenoon and evening hours like 9 am to 12 am and 3pm to $6 \mathrm{pm}$ having lowest removal rate (34 \% and 47\%) for neem and (34\% and 47\%) for moringa leaves.

\section{Conclusion}

In this proposed work, the performance evaluation of loaded solar greenhouse dryer under natural convection mode has been with neem and moringa leaves. The efficiency of the dryer depends on the duration of sunshine hours in a particular day, atmospheric pressure, air temperature, relative humidity, wind speed, rainfall etc. Solar dryers are used to dry agricultural products, herbs and marine products etc.

- Improving dryer efficiency includes finding a proper place for setting up a dryer with proper environmental setups. Using dryer setup during the month of April at Tiruvannamalai( $\left.12.2253^{\circ} \mathrm{N}, 79.0747^{\circ} \mathrm{E}\right)$ will improve the dryer for drying neem and moringa leaves.

- Analyzing and selecting suitable leaves for particular tropical area and environmental parameters gives a better result.

- Drying takes place during 12 am to $3 \mathrm{pm}$ will also improve the dryer moisture removal rate.

- Introducing the heat pump assisted solar greenhouse dryer will improve the performance and efficiency of the dryer.

- Comparatively noon hours have highest moisture removal rate $(82.93 \%)$ for neem and for moringa leaves (83.43\%). But during forenoon and evening hours like 9 am to 12 am and 3pm to $6 \mathrm{pm}$ having lowest moisture removal rate (34 \% and $47 \%$ ) for neem and (34\% and $47 \%$ ) for moringa leaves

\section{Abbreviations}

TMS-Traditional Medical System, GHD-Green House Dryer

\section{Declarations}


Availability of data and materials

Not applicable

\section{Competing interests}

The authors declare that they have no competing interests

\section{Funding}

No funding body

\section{Authors' contributions}

KR was a major contributor in experimentation and manuscript writing. NSVM analyzed old methods used in the drying process and how our test deviated from the old ones. ES contributed in equipment handling and analyzed the ways to improve the dryer with respect to parameters. All authors read and approved the final manuscript."

\section{Acknowledgements}

"Not applicable"

\section{References}

Airaodion, A. I., Olatoyinbo, P. O., Ogbuagu, U., Ogbuagu, E. O., Akinmolayan, J. D., Adekale, O. A., Awosanya, O. O., Agunbiade, A. P., Oloruntoba, A. P., Obajimi, O. O., Adeniji, A. R., \& Airaodion, E. O. (2019). Comparative Assessment of Phytochemical Content and Antioxidant Potential of Azadirachta indica and Parquetina nigrescens Leaves. 2(January), 1-14. https://doi.org/10.9734/APRJ/2019/v2i330045

Alzohairy, M. A. (2016). Therapeutics Role of Azadirachta indica (Neem ) and Their Active Constituents in Diseases Prevention and Treatment. 2016.

Amer, B. M. A., Gottschalk, K., \& Hossain, M. A. (2018). Integrated Hybrid Solar Drying System and its Drying Kinetics of Chamomile. Renewable Energy. https://doi.org/10.1016/j.renene.2018.01.055

Arabhosseini, A., Huisman, W., van Boxtel, A., \& Müller, J. (2009). Modeling of thin layer drying of tarragon (Artemisia dracunculus L.). Industrial Crops and Products, 29(1), 53-59. https://doi.org/10.1016/j.indcrop.2008.04.005

Bensebia, O., \& Allia, K. (2015). Drying and extraction kinetics of rosemary leaves: Experiments and modeling. Journal of Essential Oil-Bearing Plants, 18(1), 99-111. https://doi.org/10.1080/0972060X.2014.901620

Bhardwaj, A. K., Kumar, R., \& Chauhan, R. (2019). Experimental investigation of the performance of a novel solar dryer for drying medicinal plants in Western Himalayan region. Solar Energy, 177(November 2018), 395-407. https://doi.org/10.1016/j.solener.2018.11.007 
Boateng, L., Ashley, I., Ohemeng, A., Asante, M., \& Steiner-, M. (2018). Improving Blood Retinol Concentrations with Complementary Foods Fortified with Moringa oleifera Leaf Powder - A Pilot Study. 91(104519), 83-94.

Castillo, M., Pilatowsky, I., Castillo, B., López, E. C., \& López, A. (2018). Solar drying of Stevia ( Rebaudiana Bertoni ) leaves using direct and indirect technologies. Solar Energy, 159(June 2017), 898-907.

https://doi.org/10.1016/j.solener.2017.11.031

Chauhan, P. S., \& Kumar, A. (2016). Performance analysis of greenhouse dryer by using insulated north-wall under natural convection mode. Energy Reports, 2, 107-116. https://doi.org/10.1016/j.egyr.2016.05.004

Demir, V., Gunhan, T., Yagcioglu, A. K., \& Degirmencioglu, A. (2004). Mathematical modelling and the determination of some quality parameters of air-dried bay leaves. Biosystems Engineering, 88(3), 325-335. https://doi.org/10.1016/j.biosystemseng.2004.04.005

Doymaz, I., Tugrul, N., \& Pala, M. (2006). Drying characteristics of dill and parsley leaves. Journal of Food Engineering, 77(3), 559-565. https://doi.org/10.1016/j.jfoodeng.2005.06.070

Fatouh, M., Metwally, M. N., Helali, A. B., \& Shedid, M. H. (2006). Herbs drying using a heat pump dryer. 47, 26292643. https://doi.org/10.1016/j.enconman.2005.10.022

Folashade, I., Eniola, T., \& Olayemi, A. (2017). Journal of the Saudi Society of Agricultural Sciences Nutritive value and acceptability of bread fortified with moringa seed powder. Journal of the Saudi Society of Agricultural Sciences, 0-5. https://doi.org/10.1016/j.jssas.2017.05.002

Gulia, A., Sharma, H. K., Sarkar, B. C., Upadhyay, A., \& Shitandi, A. (2010). Changes in physico-chemical and functional properties during convective drying of aloe vera (Aloe barbadensis) leaves. Food and Bioproducts Processing, 88(2-3), 161-164. https://doi.org/10.1016/j.fbp.2009.09.001

Hassanain, A., \& others. (2011). Delete. Research in Agricultural Engineering-UZEI, 57(1), 19-29.

Hossain, M. B., Barry-ryan, C., Martin-diana, A. B., \& Brunton, N. P. (2010). Effect of drying method on the antioxidant capacity of six Lamiaceae herbs. Food Chemistry, 123(1), 85-91.

https://doi.org/10.1016/j.foodchem.2010.04.003

Janjai, S., \& Tung, P. (2005). Performance of a solar dryer using hot air from roof-integrated solar collectors for drying herbs and spices. Renewable Energy, 30(14), 2085-2095. https://doi.org/10.1016/j.renene.2005.02.006

Kant, K., Shukla, A., Sharma, A., Kumar, A., \& Jain, A. (2016). Thermal Energy storage based solar drying systems: A review Karunesh. Innovative Food Science and Emerging Technologies.

https://doi.org/10.1016/j.ifset.2016.01.007

Karthickeyan, V. (2019). Effect of combustion chamber bowl geometry modification on engine performance, combustion and emission characteristics of biodiesel fuelled diesel engine with its energy and exergy analysis. Energy, 176, 830-852. https://doi.org/10.1016/j.energy.2019.04.012

Kaya, A., \& Aydin, O. (2009). An experimental study on drying kinetics of some herbal leaves. Energy Conversion and Management, 50(1), 118-124. https://doi.org/10.1016/j.enconman.2008.08.024

Page 15/31 
Korus, A. (2011). LWT - Food Science and Technology Effect of preliminary processing , method of drying and storage temperature on the level of antioxidants in kale (Brassica oleracea $L$. var . acephala ) leaves. $L W T$ Food Science and Technology, 44(8), 1711-1716. https://doi.org/10.1016/j.Iwt.2011.03.014

Lekshmi, N. C. J. P., Sowmia, N., Viveka, S., Brindha, J. R., \& Jeeva, S. (2012). The inhibiting effect of Azadirachta indica against dental pathogens. 2(1), 6-10.

Margarita, C. T., Beatriz, C. T., Viviana, M. M. E., Ovando, S., \& Carlos, J. (2018). Technical and Experimental Study of the Solar Dehydration of the Moringa Leaf and Its Potential Integration to the Sustainable Agricultural Industry. 23, 65-73. https://doi.org/10.14207/ejsd.2018.v7n3p65

Mohamed, L. A., Kouhila, M., Jamali, A., Lahsasni, S., Kechaou, N., \& Mahrouz, M. (2005). Single layer solar drying behaviour of citrus aurantium leaves under forced convection. Energy Conversion and Management, 46(9-10), 1473-1483. https://doi.org/10.1016/j.enconman.2004.08.001

Ng, M. X., Tham, T. C., Gan, S. H., Chua, L. S., \& Aziz, R. (2017). Clinacanthus nutans Lindau: Effects of Drying Methods on the Bioactive Compounds, Colour Characteristics and Water Activity. 3937(May).

https://doi.org/10.1080/07373937.2017.1304410

Norton, B. (2014). Harnessing Solar Heat. Lecture Notes in Energy. Springer.

Pai, M. R., Acharya, L. D., \& Udupa, N. (2004). Evaluation of antiplaque activity of Azadirachta indica leaf extract gel - a 6-week clinical study. 90, 99-103. https://doi.org/10.1016/j.jep.2003.09.035

Parida, M. M., Upadhyay, C., Pandya, G., \& Jana, A. M. (2002). Inhibitory potential of neem ( Azadirachta indica Juss ) leaves on Dengue virus type-2 replication. 79, 273-278.

Peddi, B. (2018). Moringa leaf concentrate (MLC) and moringa leaf powder (MLP): a comparative study. Mlc, 2017-2018.

Prakash, O., \& Kumar, A. (2014). Solar greenhouse drying: A review. Renewable and Sustainable Energy Reviews, 29, 905-910. https://doi.org/10.1016/j.rser.2013.08.084

Premi, M., Sharma, H. K., Sarkar, B. C., \& Singh, C. (2010). Kinetics of drumstick leaves(Moringa oleifera) during convective drying. African Journal of Plant Science, 4(10), 391-400.

Rajesh, K, Karuppasamy, K. (2016). Performance evaluation of solar green house dryer for drying herbals. IJESMR, 3(6), 70-77. https://doi.org/10.5281/zenodo.55862

Selin, Ş., Elhussein, E., Bilgin, M., Lorenzo, J. M., Barba, F. J., \& Roohinejad, S. (2018). Effect of drying method on oleuropein, total phenolic content, flavonoid content, and antioxidant activity of olive (Olea europaea) leaf. August 2017. https://doi.org/10.1111/jfpp.13604

Shaw, M., Meda, V., Tabil, L., \& Opoku, A. (2006). Drying and Color Characteristics of Coriander Foliage Using Convective Thin-Layer and Microwave Drying. Journal of Microwave Power and Electromagnetic Energy, 41(2), 56-65. https://doi.org/10.1080/08327823.2006.11688559 
Singh, P., Kumar, A., \& Gupta, B. (2016). A review on thermal models for greenhouse dryers. Renewable and Sustainable Energy Reviews, November, 1-11. https://doi.org/10.1016/j.rser.2016.11.023

Sodamade, A., Bolaji, O. S., \& Adeboye, O. O. (2013). Proximate Analysis, Mineral Contents and Functional Properties of Moringa Oleifera Leaf Protein Concentrate . IOSR Journal of Applied Chemistry (IOSR-JAC), 4(6), 47-51.

Taylor, P., Prakash, O., \& Kumar, A. (2013). International Journal of Green Energy Historical Review and Recent Trends in Solar Drying Systems. September 2014, 37-41. https://doi.org/10.1080/15435075.2012.727113

Taylor, P., Tussolini, L., Oliveira, J. S. De, Freire, F. B., Freire, J. T., \& Zanoelo, E. F. (2014). Drying Technology: An International Journal Thin-Layer Drying of Mate Leaves (Ilex paraguariensis) in a Conveyor-Belt Dryer: A SemiAutomatic Control Strategy Based on a Dynamic Model Thin-Layer Drying of Mate Leaves (Ilex paraguariensis ) in a Conve. October, 37-41. https://doi.org/10.1080/07373937.2014.900504

Tham, T. C., Ng, M. X., Gan, S. H., Chua, L. S., Aziz, R., Chuah, L. A., Hii, C. L., Ong, S. P., Chin, N. L., \& Law, C. L. (2017). Effect of ambient conditions on drying of herbs in solar greenhouse dryer with integrated heat pump. Drying Technology, 35(14), 1721-1732. https://doi.org/10.1080/07373937.2016.1271984

Thurber, M. D., \& Fahey, J. W. (n.d.). Ecology of Food and Nutrition Adoption of Moringa oleifera to Combat UnderNutrition Viewed Through the Lens of the "Diffusion of Innovations " Theory. September 2013, 37-41. https://doi.org/10.1080/03670240902794598

Vidaller, C. (2018). Adaptive differentiation among populations of the Mediterranean dry grassland species Brachypodium retusum: The role of soil conditions, grazing , and humidity. 105(6), 1-10. https://doi.org/10.1002/ajb2.1116

Ziegler, T., \& Ziegler, T. (2019). Primary energy demand and energy costs of fixed-bed drying using the example of chamomile flowers the example of chamomile flowers. Drying Technology, O(0), 1-14.

https://doi.org/10.1080/07373937.2019.1580290

\section{Tables}

Table .1. Moringa leaves nutritive values

\begin{tabular}{|l|l|}
\hline Minerals & Minerals Concentration $(\mathrm{Mg} / 100 \mathrm{~g})$ \\
\hline $\mathrm{K}$ & $23.20 \pm 0.31$ \\
\hline $\mathrm{Na}$ & $214.00 \pm 0.02$ \\
\hline $\mathrm{Ca}$ & $723.00 \pm 0.04$ \\
\hline $\mathrm{Mg}$ & $677 \pm 0.16$ \\
\hline $\mathrm{P}$ & $5.00 \pm 0.12$ \\
\hline $\mathrm{Fe}$ & $187.00 \pm 0.03$ \\
\hline $\mathrm{Mn}$ & $252.00 \pm 0.15$ \\
\hline $\mathrm{Cu}$ & $55.00 \pm 0.08$ \\
\hline $\mathrm{Zn}$ & $548.00 \pm 0.04$ \\
\hline
\end{tabular}


Table 2. Comparative analysis of leaves drying in previous experimental work

\begin{tabular}{|c|c|c|c|c|c|}
\hline Herbals & $\begin{array}{l}\text { Types of } \\
\text { solar dryer }\end{array}$ & Methods \&models & $\begin{array}{l}\text { Parameter governed for } \\
\text { drying samples. }\end{array}$ & Health Benefits & References \\
\hline $\begin{array}{l}\text { 1.Jesticia } \\
\text { adhatoda(adhatoda) } \\
\text { 2.Solanum trilobatum } \\
\text { (Thuthuvalai) } \\
\text { 3.Phylanodiflora(podudhalai) } \\
\text { 4.Aistrnia } \\
\text { scholaris(pallamaram) }\end{array}$ & $\begin{array}{l}\text { Solar } \\
\text { greenhouse } \\
\text { dryer }\end{array}$ & - & $\begin{array}{l}\text { Temperature } \\
\text { solar intensity, mass flow } \\
\text { rate,slope angle of the } \\
\text { dryer }\end{array}$ & $\begin{array}{l}\text { 1.Cold,cough,BB,TB,fever,asthma } \\
\text { 2.Cold,cough,fever } \\
\text { 3.Ulcer,anti-dandruff medicine } \\
\text { 4.Nausea and vomiting ,dry } \\
\text { mouth, muscle twitch, etc }\end{array}$ & $\begin{array}{l}\text { (Rajesh, K, } \\
\text { Karuppasazmy, } \\
\text { 2016) }\end{array}$ \\
\hline $\begin{array}{l}\text { Moringa oleifera (drumstick } \\
\text { leaves) }\end{array}$ & $\begin{array}{l}\text { Electric } \\
\text { convective } \\
\text { type dryer }\end{array}$ & $\begin{array}{l}\text { Fick's diffusion } \\
\text { Verma model }\end{array}$ & Temperature, color & $\begin{array}{l}\text { Immunity booster, Asthma, } \\
\text { Diabetes, lactation, malnutrition, } \\
\text { menopausal symptoms, etc }\end{array}$ & $\begin{array}{l}\text { (Premi et al., } \\
\text { 2010) }\end{array}$ \\
\hline $\begin{array}{llll}\text { Laurus } & \text { nobilis } & \text { L } & \text { (Bay } \\
\text { leaves) } & & & \\
\end{array}$ & $\begin{array}{l}\text { Convection } \\
\text { drying }\end{array}$ & $\begin{array}{l}\text { Lewis,page, } \\
\text { Logarithmic, } \\
\text { Henderson and Pabis } \\
\text { Modified Page }\end{array}$ & $\begin{array}{l}\text { Drying } \quad \text { time(initial } \\
\text { moisture content is low) }\end{array}$ & $\begin{array}{l}\text { stimulatory, emetic, and as an } \\
\text { insect repellent, etc }\end{array}$ & $\begin{array}{c}\text { (Demir et al., } \\
2004)\end{array}$ \\
\hline $\begin{array}{cc}\text { Coriandrum sativum } & \mathrm{L} \\
\text { Umbelliferae(Coriander) } & \end{array}$ & $\begin{array}{l}\text { Thin layer } \\
\text { convection } \\
\text { and } \\
\text { microwave } \\
\text { dryers }\end{array}$ & Page model & $\begin{array}{l}\text { Airflow,temperature, } \\
\text { relativehumidity, mass }\end{array}$ & $\begin{array}{l}\text { Treat worms,joint pains, } \\
\text { dehydration, and indigestion, } \\
\text { rheumatism, etc }\end{array}$ & $\begin{array}{l}\text { (Shaw et al., } \\
\text { 2006) }\end{array}$ \\
\hline $\begin{array}{l}\text { Rosmarinus officinalis } \\
\text { L(Rosemary Leaves) }\end{array}$ & $\begin{array}{l}\text { Oven and } \\
\text { Microwave } \\
\text { dryer }\end{array}$ & $\begin{array}{l}\text { Page, } \\
\text { Henderson and Pabis, } \\
\text { Lewis, } \\
\text { Logarithmic,Fick }\end{array}$ & Temperature & $\begin{array}{l}\text { cough. } \\
\text { Headache. } \\
\text { Indigestion. etc }\end{array}$ & $\begin{array}{l}\text { (Bensebia \& } \\
\text { Allia, 2015) }\end{array}$ \\
\hline $\begin{array}{l}\begin{array}{l}\text { Artemisia dracunculus } \\
\text { (tarragon leaves) }\end{array} \\
\text { L. }\end{array}$ & Lab dryer & Page & Temperature,RH,material & $\begin{array}{l}\text { Digestion problems. } \\
\text { Menstrual problems. } \\
\text { Toothaches. Nausea and } \\
\text { vomiting, etc }\end{array}$ & $\begin{array}{l}\text { (Arabhosseini } \\
\text { et al., 2009) }\end{array}$ \\
\hline $\begin{array}{l}\text { Hibiscus sabdariffa } \\
\text { (rosella flowers) } \\
\text { Citrus limon (lemon-grasses) }\end{array}$ & $\begin{array}{l}\text { bin-type } \\
\text { dryer }\end{array}$ & - & Temperature & $\begin{array}{l}\text { cure skin diseases, repair brain } \\
\text { tissue, Prevent the growth of } \\
\text { cancer cells, etc. } \\
\text { Relieving pain, Boosting red } \\
\text { blood cell, etc }\end{array}$ & $\begin{array}{l}\text { (Janjai \& Tung, } \\
\text { 2005) }\end{array}$ \\
\hline $\begin{array}{l}\text { Urtica dioica(mint) Mentha } \\
\text { spicata } L \text { (nettle) }\end{array}$ & $\begin{array}{l}\text { Experimental } \\
\text { setup } \\
\text { components: } \\
\text { Drying } \\
\text { channel,Air } \\
\text { blowing } \\
\text { channel }\end{array}$ & $\begin{array}{l}\text { gravimetric } \\
\text { method(Sorption } \\
\text { isotherm) }\end{array}$ & $\begin{array}{l}\text { Velocity } \mathrm{U} \text {, temperature } \\
\mathrm{T} \text {, relative humidity } \mathrm{u}\end{array}$ & $\begin{array}{l}\text { antioxidant, Indigestion and } \\
\text { gas,normal cold,pain relief, etc } \\
\text { pain relief, wound healing }\end{array}$ & $\begin{array}{l}\text { (Kaya \& Aydin, } \\
\text { 2009) }\end{array}$ \\
\hline $\begin{array}{ll}\text { Citrus } & \text { aurantium(Bitter } \\
\text { orange) } & \end{array}$ & $\begin{array}{l}\text { Solar dryer } \\
\text { used in } \\
\text { indirect } \\
\text { forced } \\
\text { convection } \\
\text { method }\end{array}$ & Midilli-Kucuk, & Drying air Temperature & $\begin{array}{l}\text { increase fat breakdown, } \\
\text { healthy ,permanent weight } \\
\text { loss,etc }\end{array}$ & $\begin{array}{l}\text { (Mohamed et } \\
\text { al., 2005) }\end{array}$ \\
\hline Salvia officinalis L(sage) & $\begin{array}{l}\text { Unglazed } \\
\text { perforated } \\
\text { passive solar } \\
\text { dryer }\end{array}$ & - & Temperature & $\begin{array}{l}\text { carminative, diuretic, antiheroic, } \\
\text { analgesic, expectorant, } \\
\text { disinfectant, gargleetc }\end{array}$ & $\begin{array}{l}\text { (Hassanain \& } \\
\text { others, 2011) }\end{array}$ \\
\hline $\begin{array}{l}\text { aloe vera (Aloe barbadensis) } \\
\text { leaves[12] }\end{array}$ & $\begin{array}{l}\text { convective } \\
\text { drying }\end{array}$ & $\begin{array}{l}\text { Physico-chemical } \\
\text { analysis(Moisture,ash, } \\
\text { protein,crude fat and } \\
\text { crudefibre) The } \\
\text { centrifuge method } \\
\text { (Water absorption) }\end{array}$ & $\begin{array}{l}\text { pH Wettability (s), } \\
\text { Water absorption } \\
\text { capacity,Temperature }\end{array}$ & $\begin{array}{l}\text { Contains iron,dietary fibre, } \\
\text { antioxidants }\end{array}$ & $\begin{array}{l}\text { (Gulia et al., } \\
\text { 2010) }\end{array}$ \\
\hline
\end{tabular}


Table 3.Instruments used during experimentations.

\begin{tabular}{|c|c|c|c|c|c|c|}
\hline S. No. & Device used & Model & Make & Parameters & Accuracy & Equipment Used \\
\hline 1. & Anemometer & $\begin{array}{c}\text { Gm816 } \\
\text { Pocket } \\
\text { Lcd }\end{array}$ & Amicisense & Wind Speed & $\begin{array}{c} \pm 0.01 \\
\mathrm{~m} / \mathrm{s})\end{array}$ & \\
\hline 2 & Weighing Scale & $\begin{array}{c}\text { Kea-20 } \\
\text { kgm }\end{array}$ & Atlas & Weight & $\pm 2 g$ & \\
\hline 3 & $\begin{array}{l}\text { Thermo- } \\
\text { Hygrometer }\end{array}$ & 103-СТH & $\begin{array}{c}\mathrm{HTC} \\
\text { Instrument }\end{array}$ & $\begin{array}{c}\text { Temperature } \\
\text { and } \\
\text { Humidity }\end{array}$ & $\begin{array}{c} \pm 0.5^{\circ} \mathrm{C}, \pm \\
3 \%\end{array}$ & \\
\hline 4 & $\begin{array}{c}\text { Pyranometer(Lux } \\
\text { meter) }\end{array}$ & $\begin{array}{l}\text { UNI-T } \\
\text { UT383 }\end{array}$ & AmiciSense & $\begin{array}{c}\text { Solar } \\
\text { intensity }\end{array}$ & $\pm 0.5 \mathrm{~W} / \mathrm{m}^{2}$ & \\
\hline
\end{tabular}

Table 4. Relationship between heat gain and slope angle during moringa leaves drying

\begin{tabular}{|c|c|c|c|}
\hline S.No & Slope angle (degree) & Heat gain(w) & Heat gain (w) \\
\hline & B & During 12 am to 3 pm & During 3 pm to 6 pm \\
\hline 1 & 20 & 471.29 & 356.84 \\
\hline 2 & 25 & 462.34 & 347.89 \\
\hline 3 & 30 & 452.63 & 338.18 \\
\hline 4 & 35 & 441.89 & 327.44 \\
\hline 5 & 40 & 429.75 & 315.30 \\
\hline 6 & 45 & 415.69 & 301.24 \\
\hline 7 & 50 & 398.94 & 284.49 \\
\hline 8 & 55 & 378.29 & 263.84 \\
\hline 9 & 60 & 351.75 & 201.31 \\
\hline 10 & 65 & 315.76 & \\
\hline
\end{tabular}

Table 5. Relationship between heat gain and slope angle during neem leaves drying 


\begin{tabular}{|c|c|c|c|}
\hline S.No & Slope Angle (degree) & Heat gain(w) & Heat gain (w) \\
\hline 1 & B & During 12 am to 3 pm & During 3 pm to 6 pm \\
\hline 2 & 20 & 342.63 & 272.37 \\
\hline 3 & 25 & 333.68 & 263.42 \\
\hline 4 & 30 & 323.97 & 253.71 \\
\hline 5 & 35 & 313.23 & 242.97 \\
\hline 6 & 40 & 301.09 & 230.83 \\
\hline 7 & 45 & 287.03 & 216.77 \\
\hline 8 & 50 & 270.28 & 179.37 \\
\hline 9 & 55 & 249.63 & 152.83 \\
\hline 10 & 60 & 223.09 & 116.84 \\
\hline
\end{tabular}

Table 6:Moisture removal rate in neem leaves

\begin{tabular}{|c|c|c|c|}
\hline \multirow{2}{*}{ date } & \multicolumn{3}{|c|}{ Moisture Removal rate (\%) } \\
\cline { 2 - 4 } & $9 \mathrm{am}$ to $12 \mathrm{am}$ & $12 \mathrm{am}$ to $3 \mathrm{pm}$ & $3 \mathrm{pm}$ to $6 \mathrm{pm}$ \\
\hline day $1(11 / 4)$ & 22.00 & 55.84 & 44.16 \\
\hline day 2(12/4) & 28.51 & 56.63 & 47.15 \\
\hline day 3(14/4) & 24.72 & 63.93 & 42.52 \\
\hline day 4(16/4) & 34.73 & 82.93 & 45.39 \\
\hline day 5(17/4) & 33.33 & 54.32 & 47.68 \\
\hline day 6(18/4) & 23.34 & 65.75 & 46.22 \\
\hline
\end{tabular}

Table 7.Moisture removal rate in moringa leaves

\begin{tabular}{|c|c|c|c|}
\hline \multirow{2}{*}{ Date } & \multicolumn{3}{|c|}{ Moisture Removal rate (\%) } \\
\cline { 2 - 4 } & $9 \mathrm{am}$ to $12 \mathrm{am}$ & $12 \mathrm{am}$ to $3 \mathrm{pm}$ & $3 \mathrm{pm}$ to $6 \mathrm{pm}$ \\
\hline day $1(11 / 4)$ & 23.39 & 55.56 & 46.90 \\
\hline day 2(12/4) & 28.51 & 58.54 & 47.15 \\
\hline day 3(14/4) & 28.48 & 62.50 & 43.84 \\
\hline day $4(16 / 4)$ & 34.73 & 63.95 & 34.27 \\
\hline day 5(17/4) & 31.60 & 83.43 & 46.50 \\
\hline day 6(18/4) & 21.90 & 65.75 & 43.08 \\
\hline
\end{tabular}




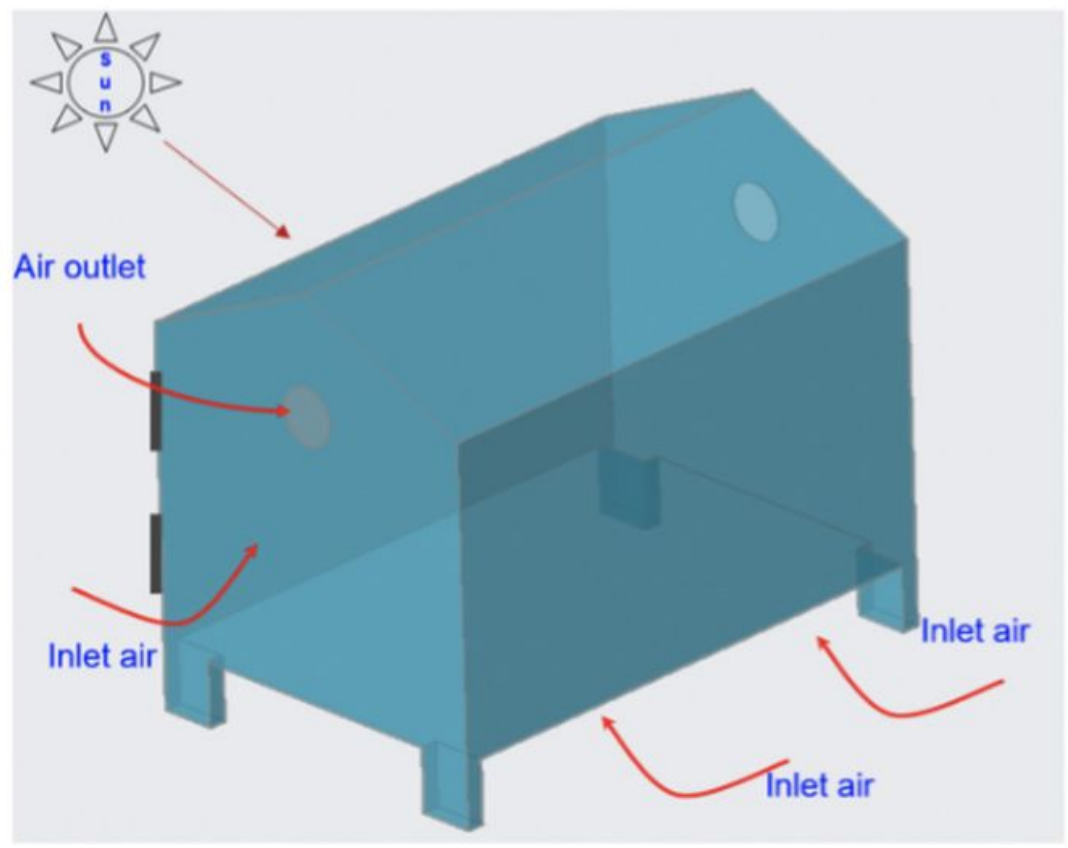

Fig.1.a Greenhouse dryer (3D view)

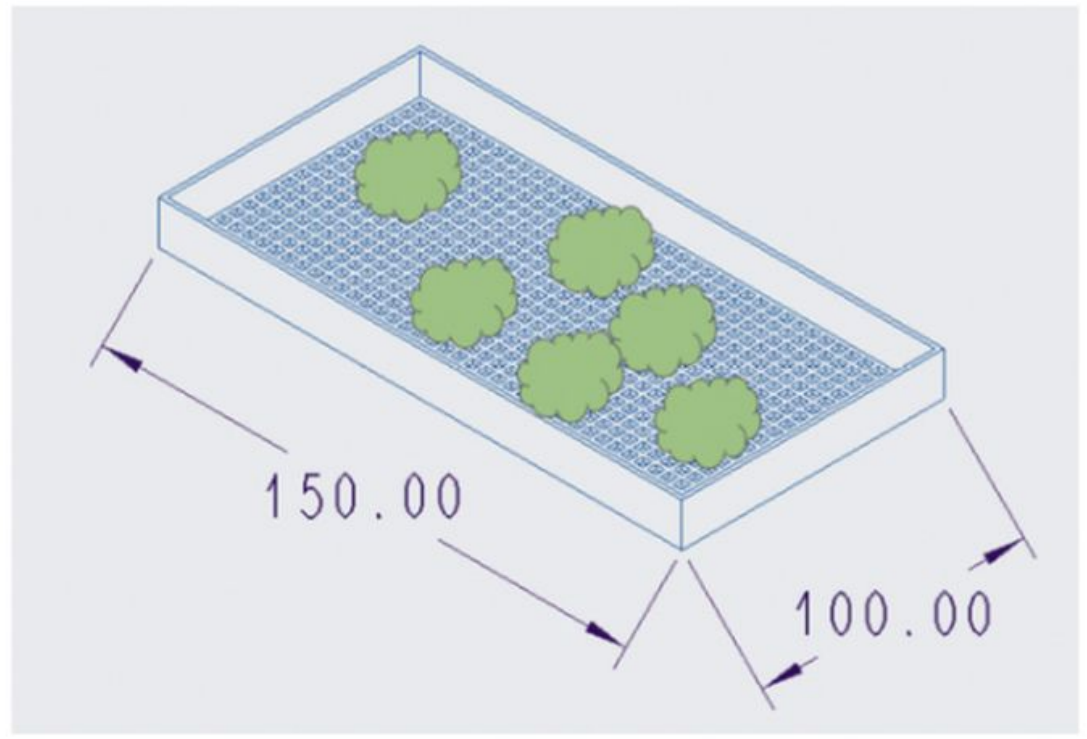

Fig. 1.b. Tary structure(Schematic view)

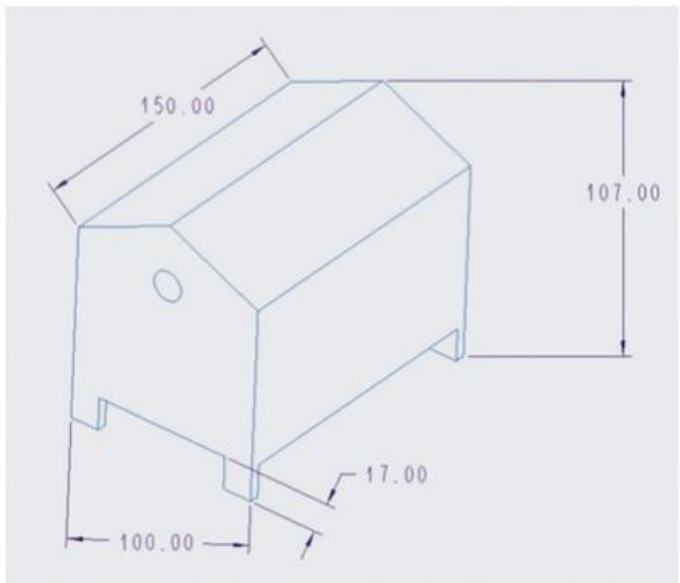

Fig. 1.c. Experimental set up(Schematic view)

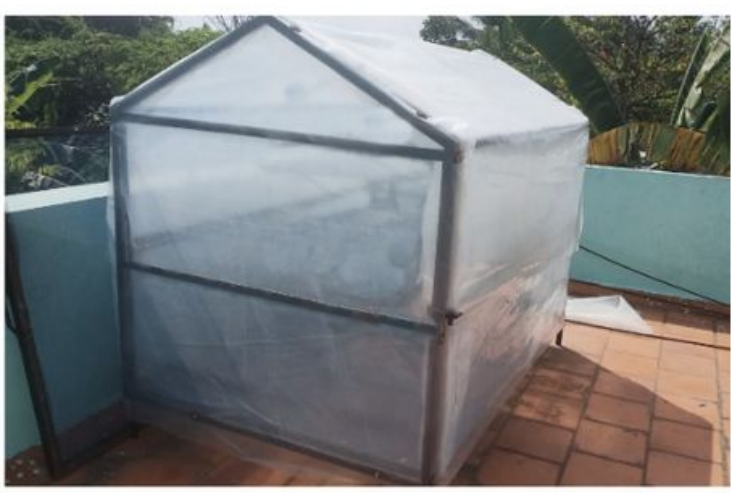

Fig. 1.d. Experimental set up(Phographic view)

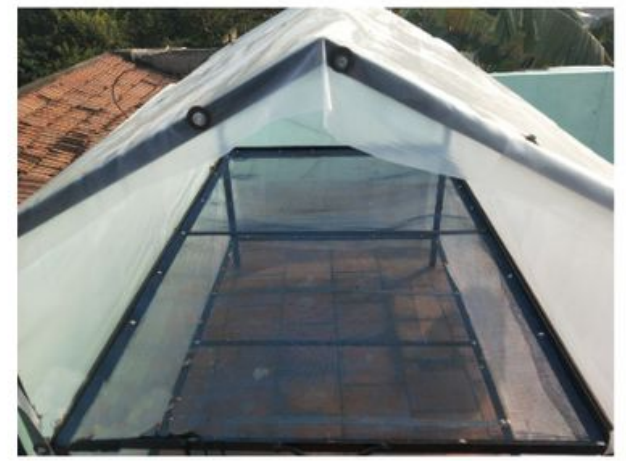

Fig. 1.e. Tray structure (Phographic view)

\section{Figure 1}

a. Greenhouse dryer (3D view). b. Tary structure(Schematic view). c. Experimental set up(Schematic view). d. Experimental set up(Phographic view). e. Tray structure (Phographic view). 


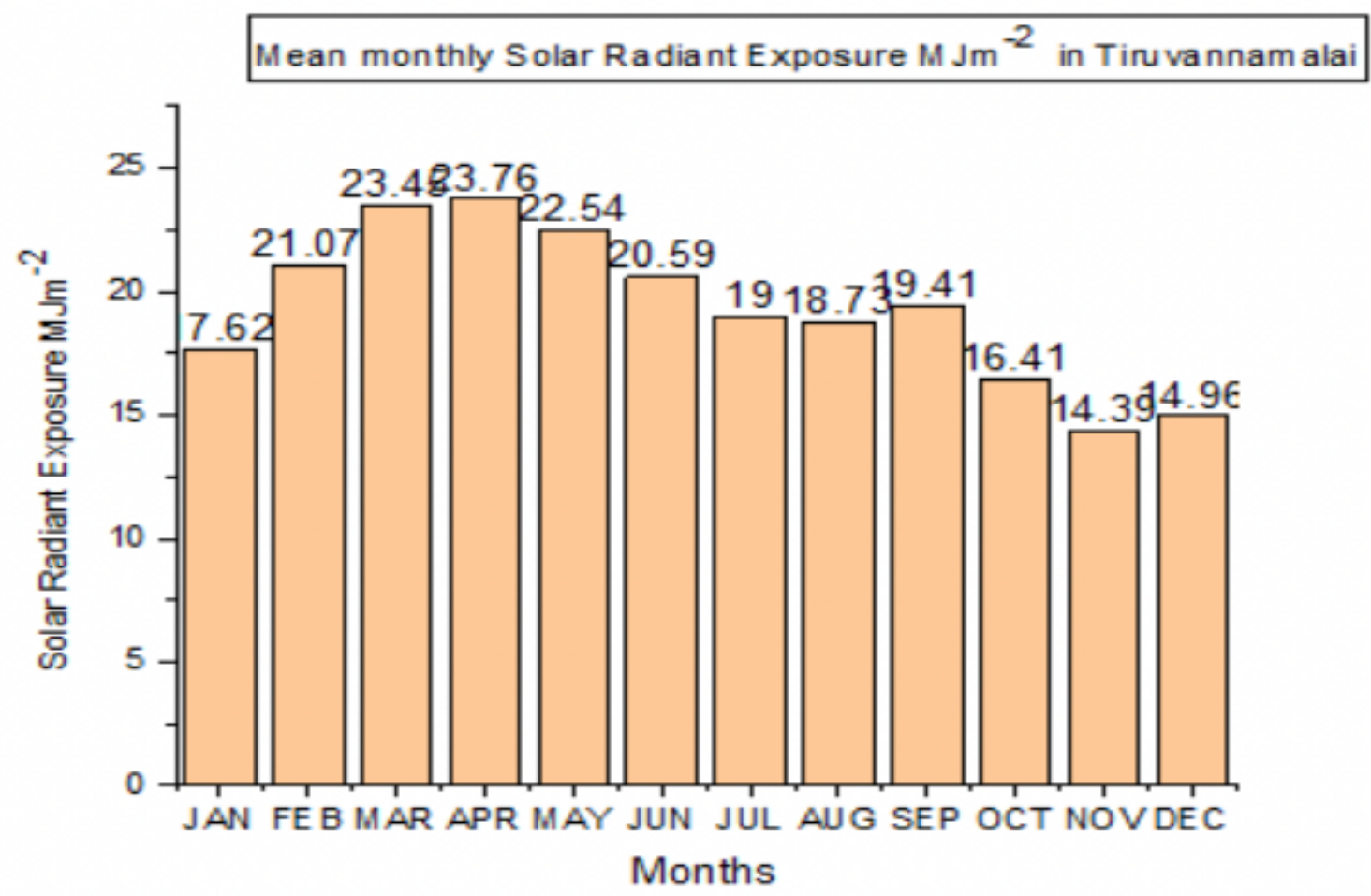

Figure 2

Mean monthly solar radiant exposure in Truvannamalai

Global solar radiant exposure (M Jm-2) at Tiruvannamalai in April

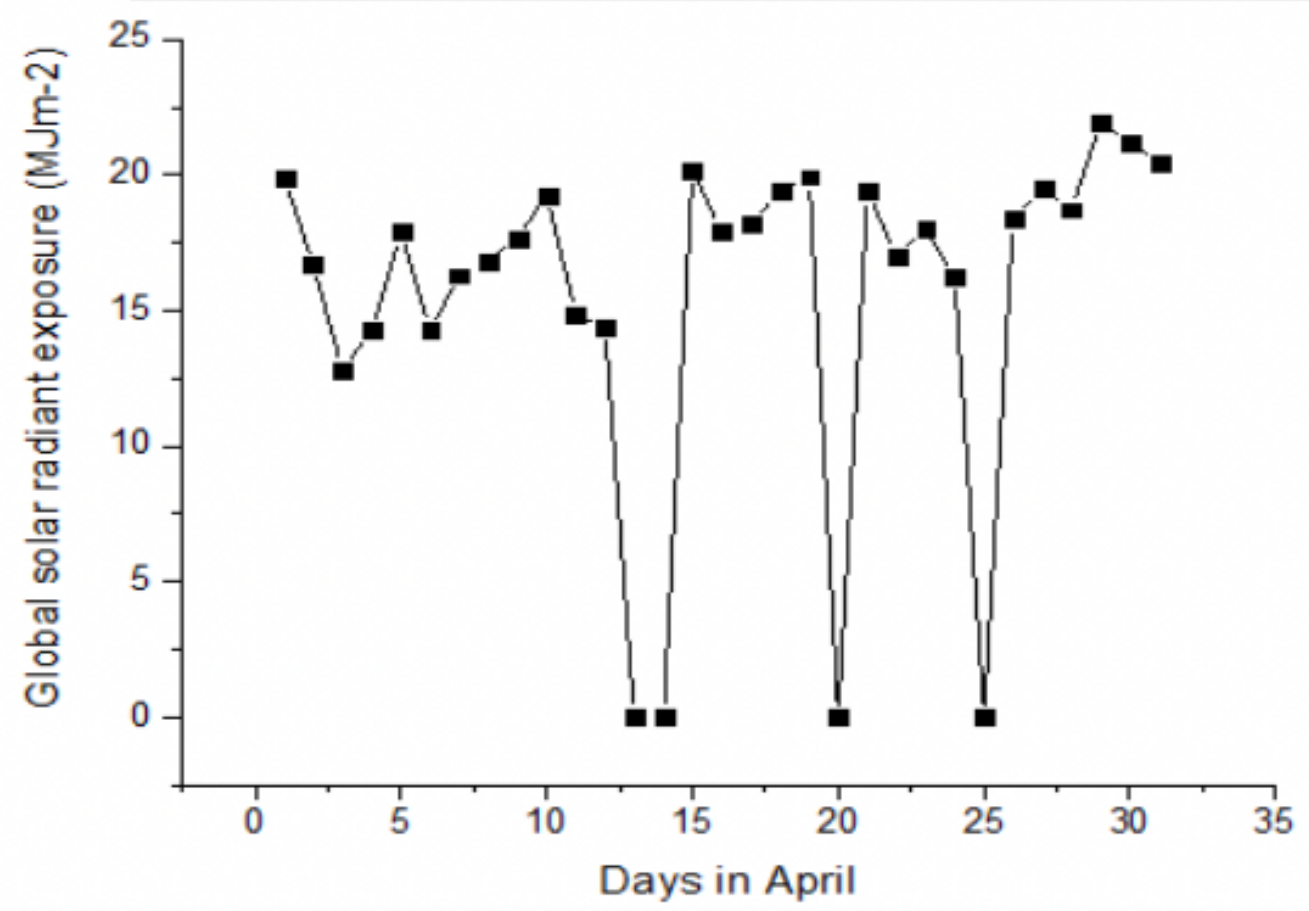

Figure 3 


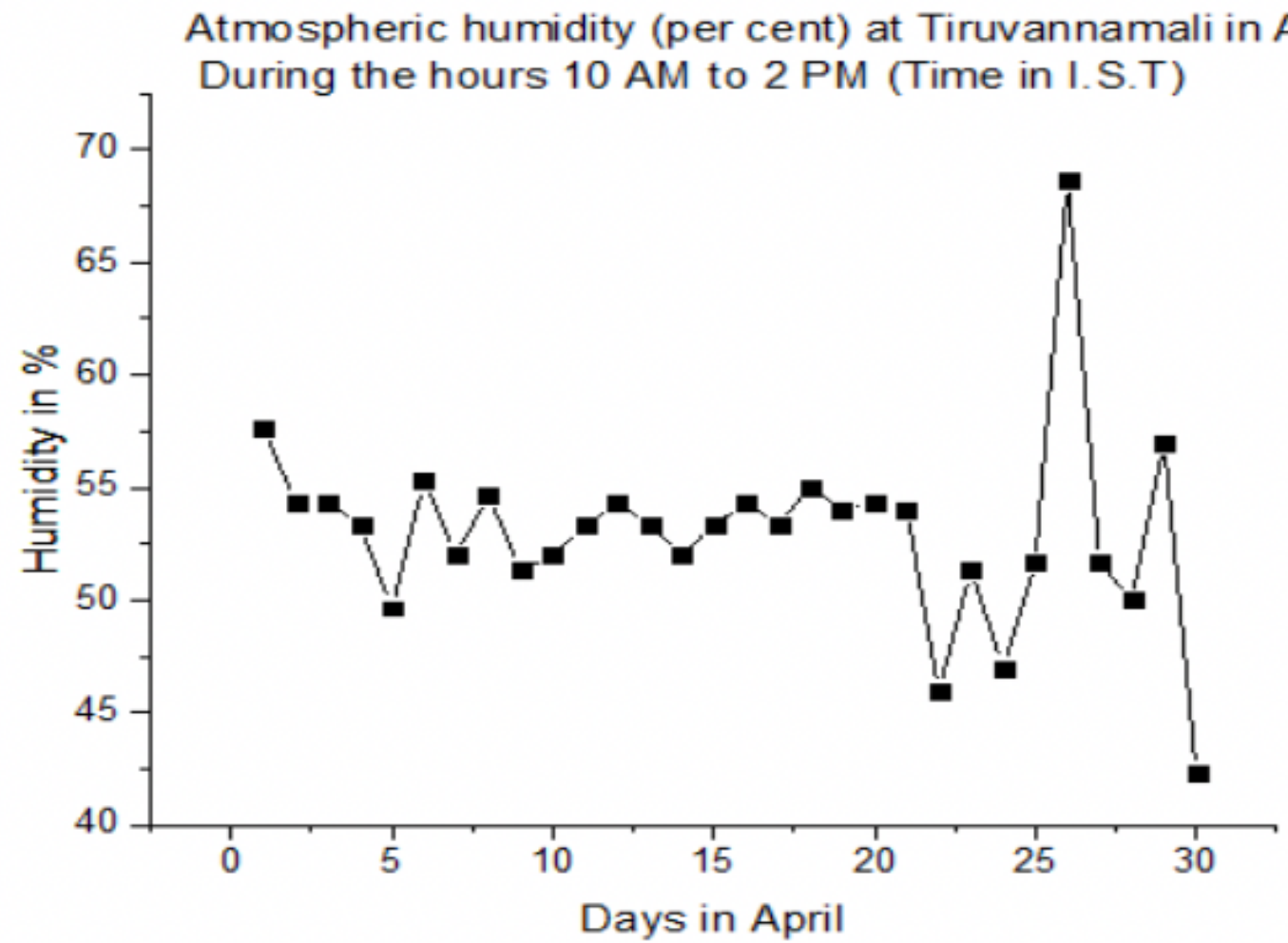

Figure 4

Humidity variations in april month

Relationship between Temperature and Humidity at thiruvannamalai in April

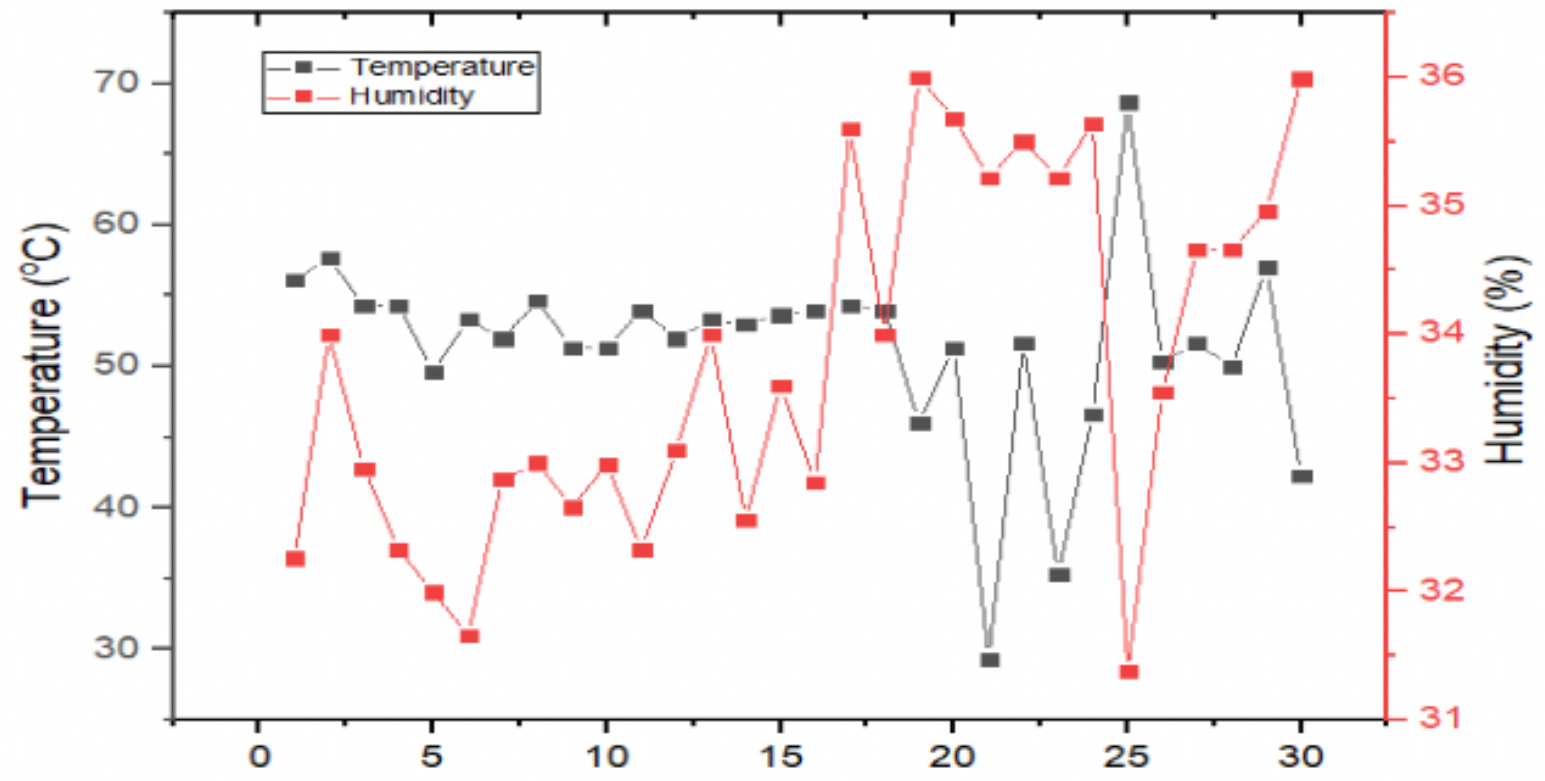

Figure 5 
Relationship between Temperature and Humidity at Tiruvannamalai in April month
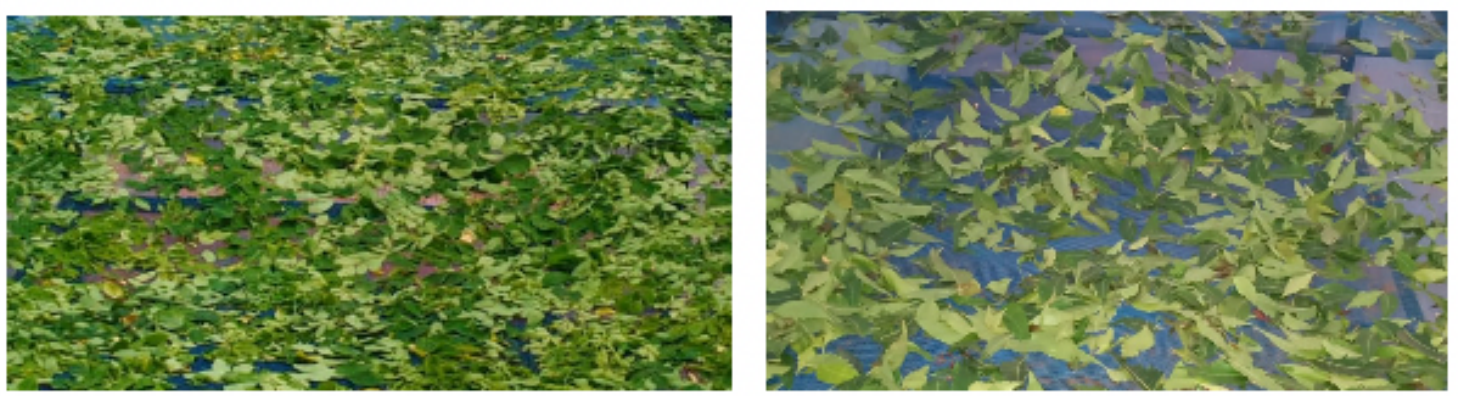

\section{Figure 6}

Samples used in the drying(neem and moringa)

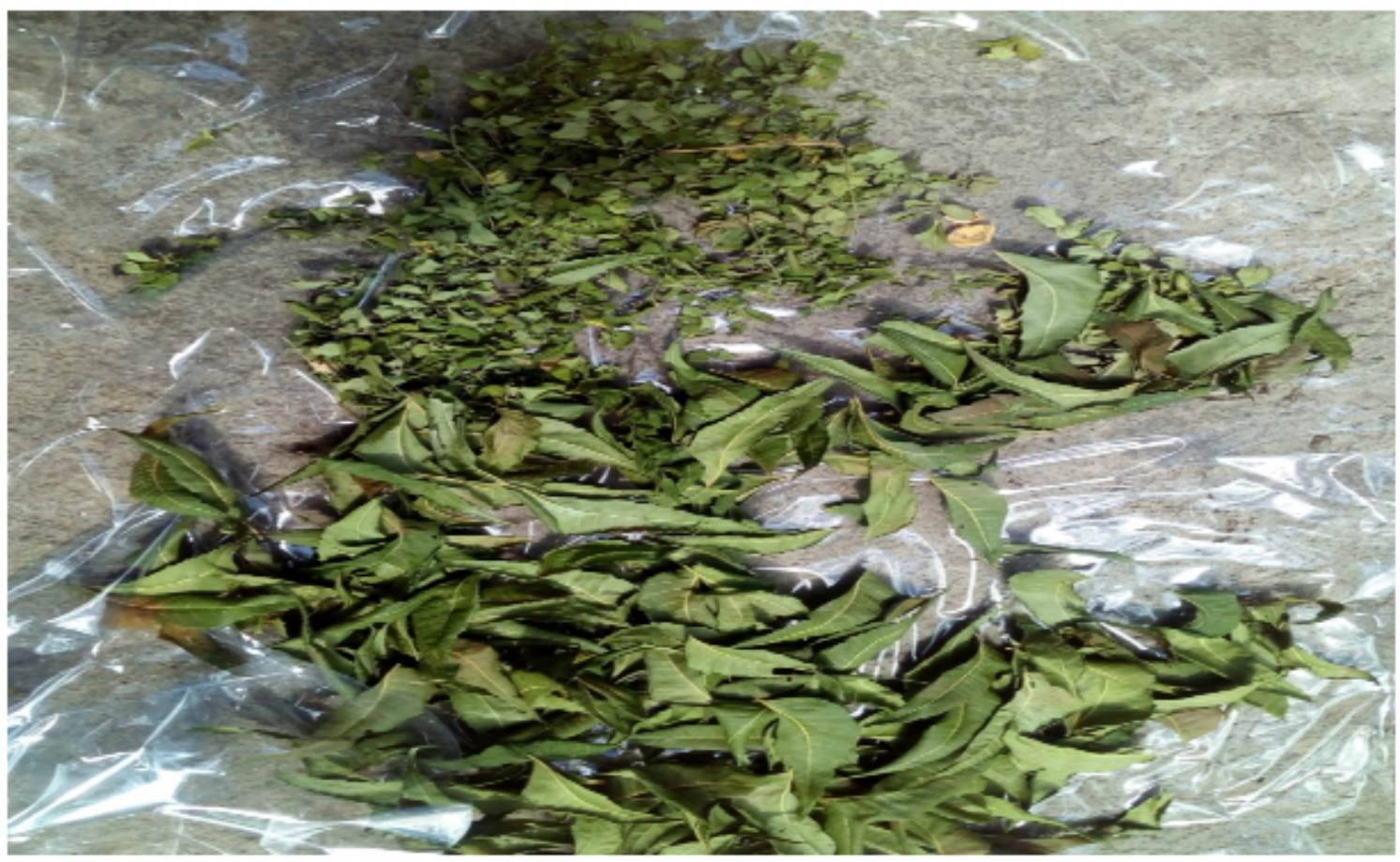

\section{Figure 7}

Open Sun Drying(neem and moringa ) (Photographic view) 


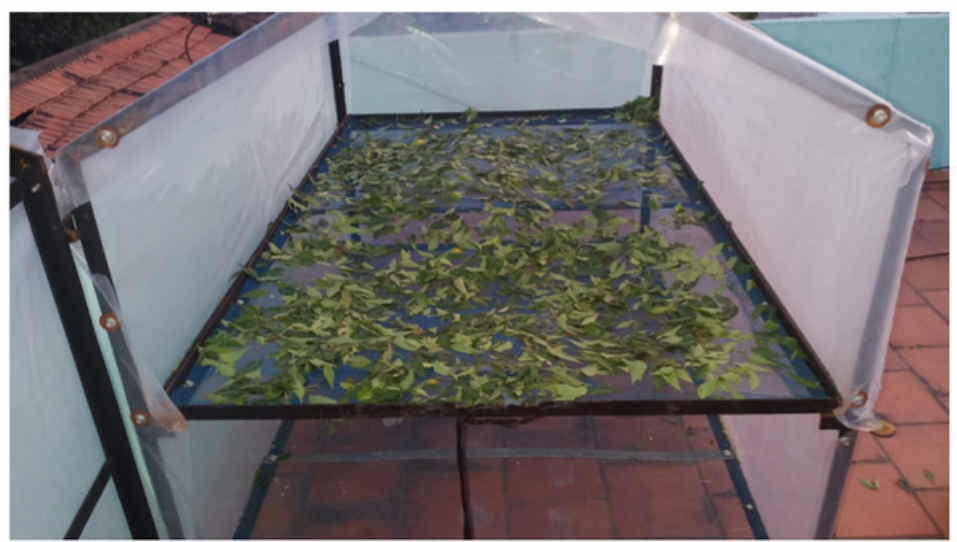

Fig .8 a .Neem leaves drying inside the green house dryer (Photographic view)

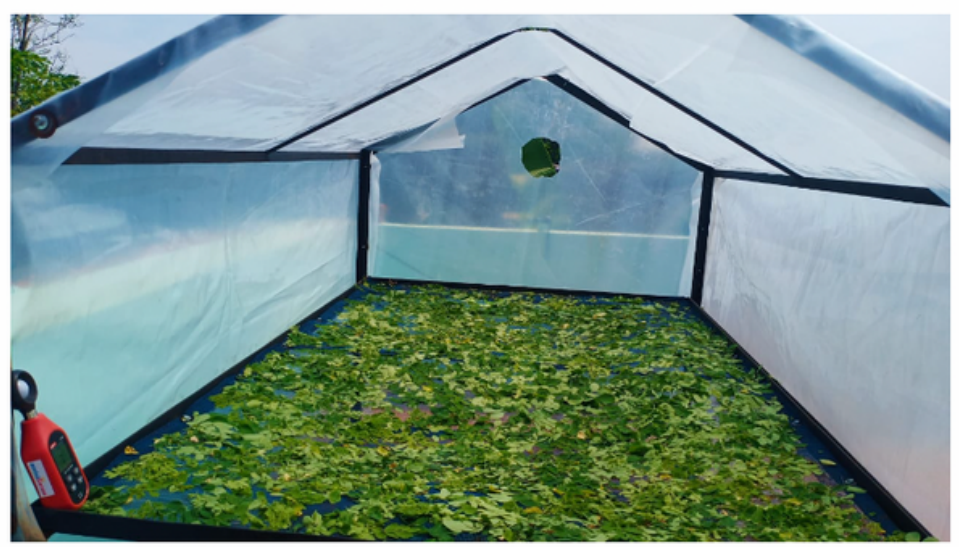

Fig .8 b .Moringa leaves drying inside the green house dryer (Photographic view)

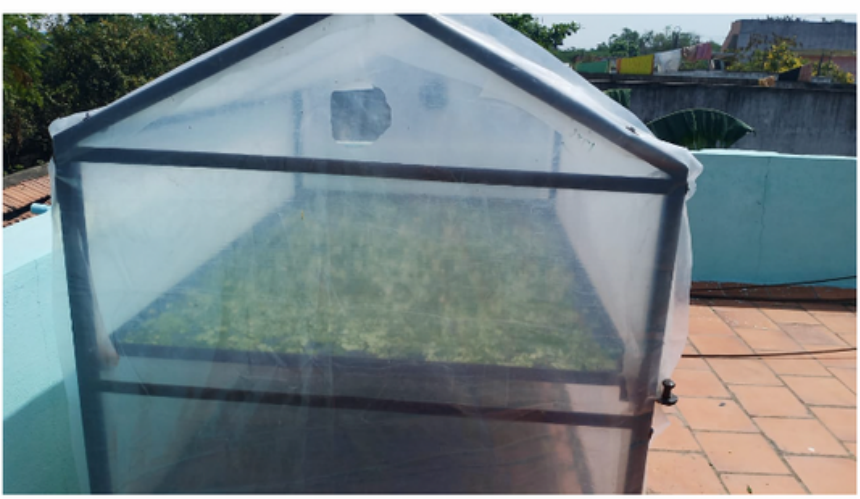

Fig .8 c Few hours later (Photographic view)

\section{Figure 8}

a .Neem leaves drying inside the green house dryer (Photographic view). b .Moringa leaves drying inside the green house dryer (Photographic view). c. Few hours later (Photographic view)

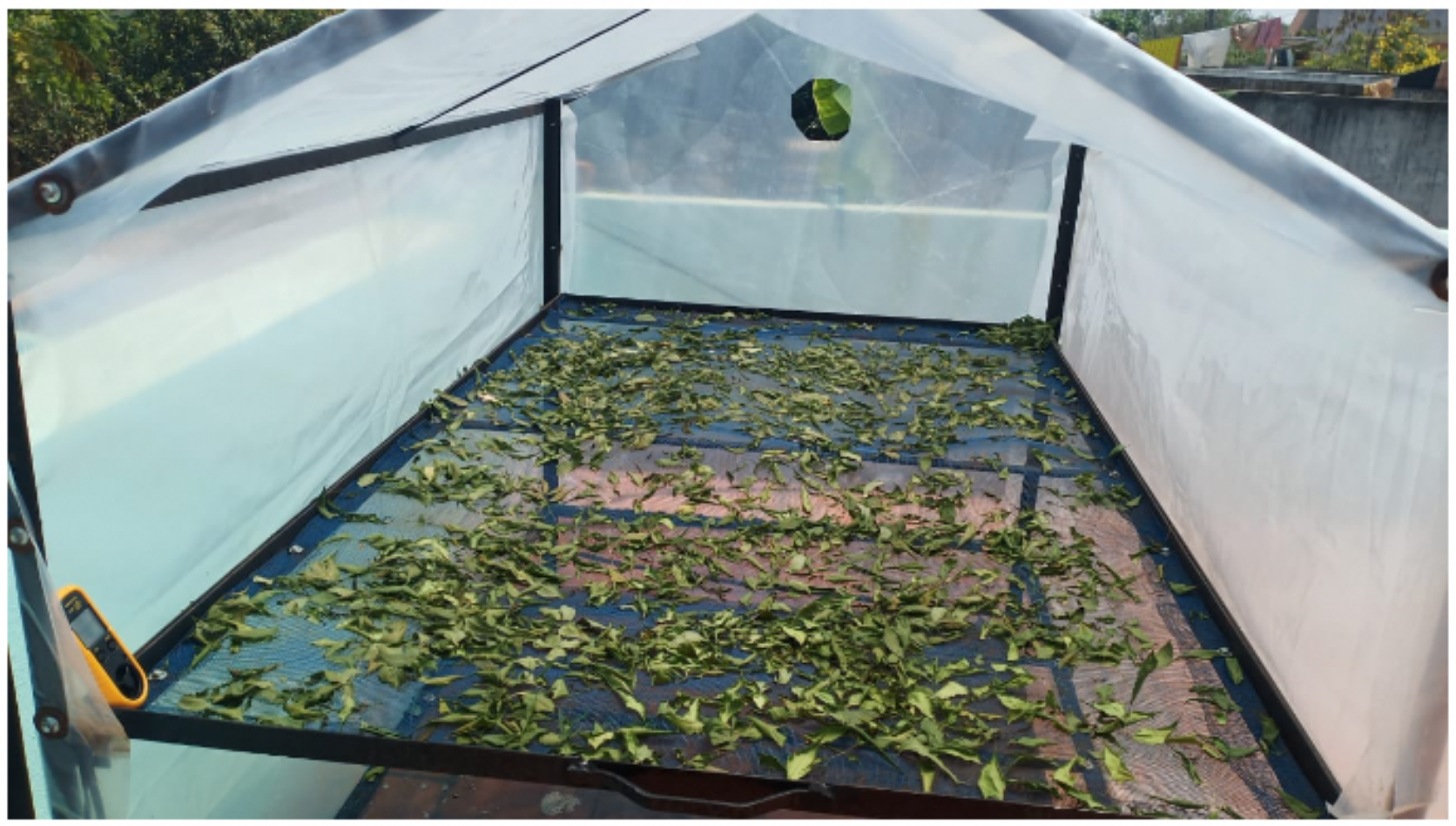


Figure 9

End of drying (Photographic view)

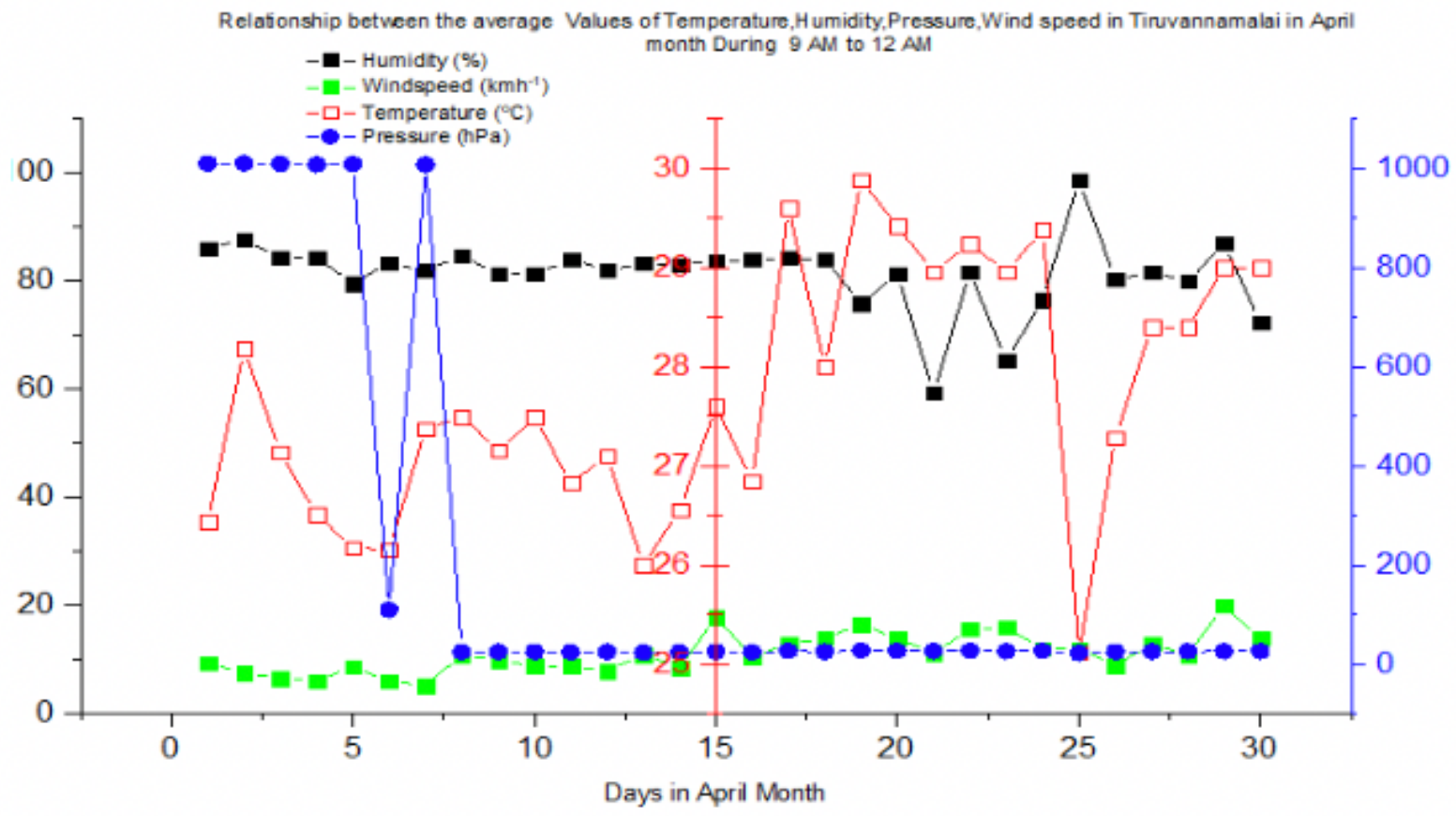

Figure 10

Relationship between the average values of temperature, humidity, pressure, wind speed in Tiruvannamalai during April month from 9 am to am

Relationship between the average Values of Temperature, Humidity, Pressure,Wind speed in Tiruvannamalai in April month During 12 AM to 3 PIA

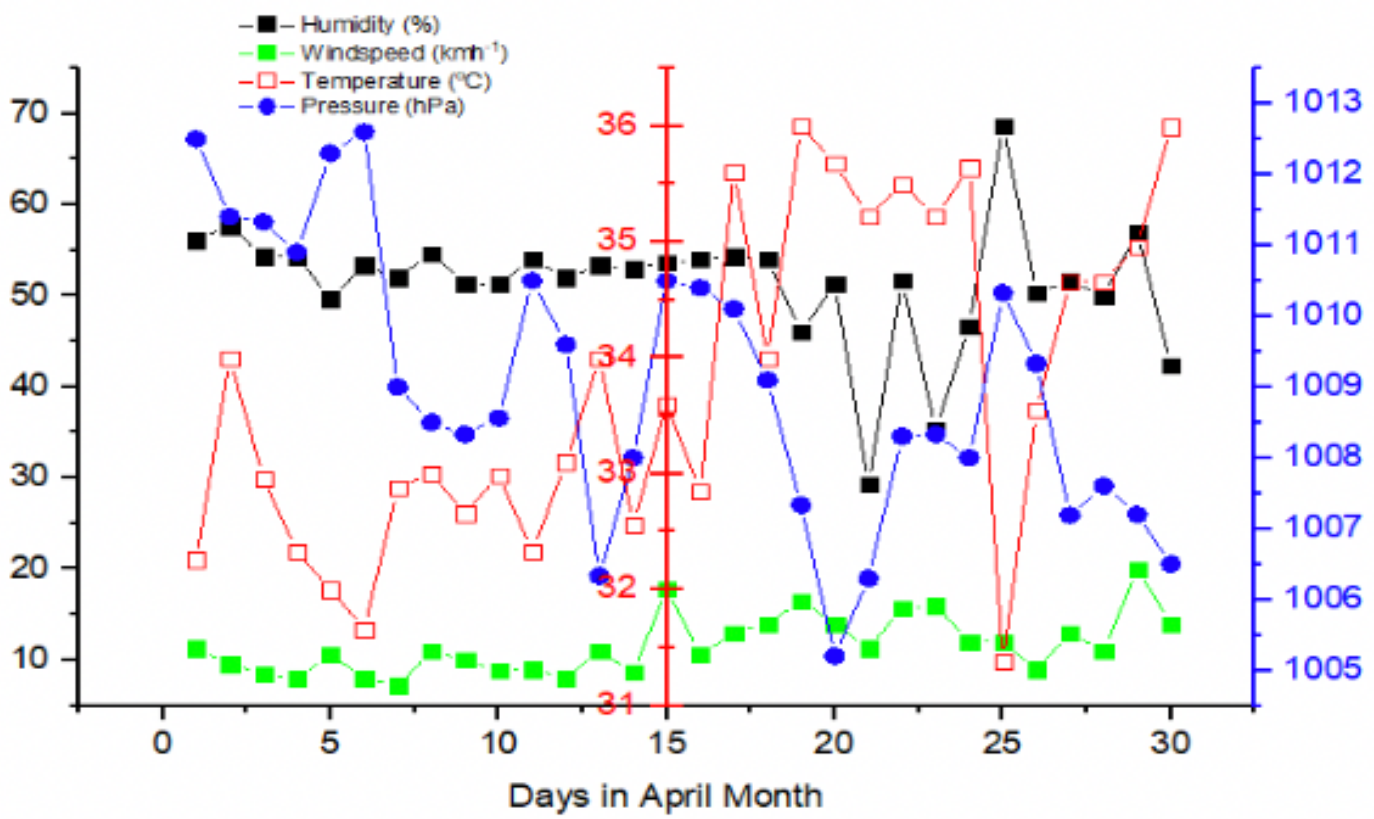

Figure 11 
Relationship between the average values of temperature, humidity, pressure, wind speed in Tiruvannamalai during April month from 12 am to 3 pm

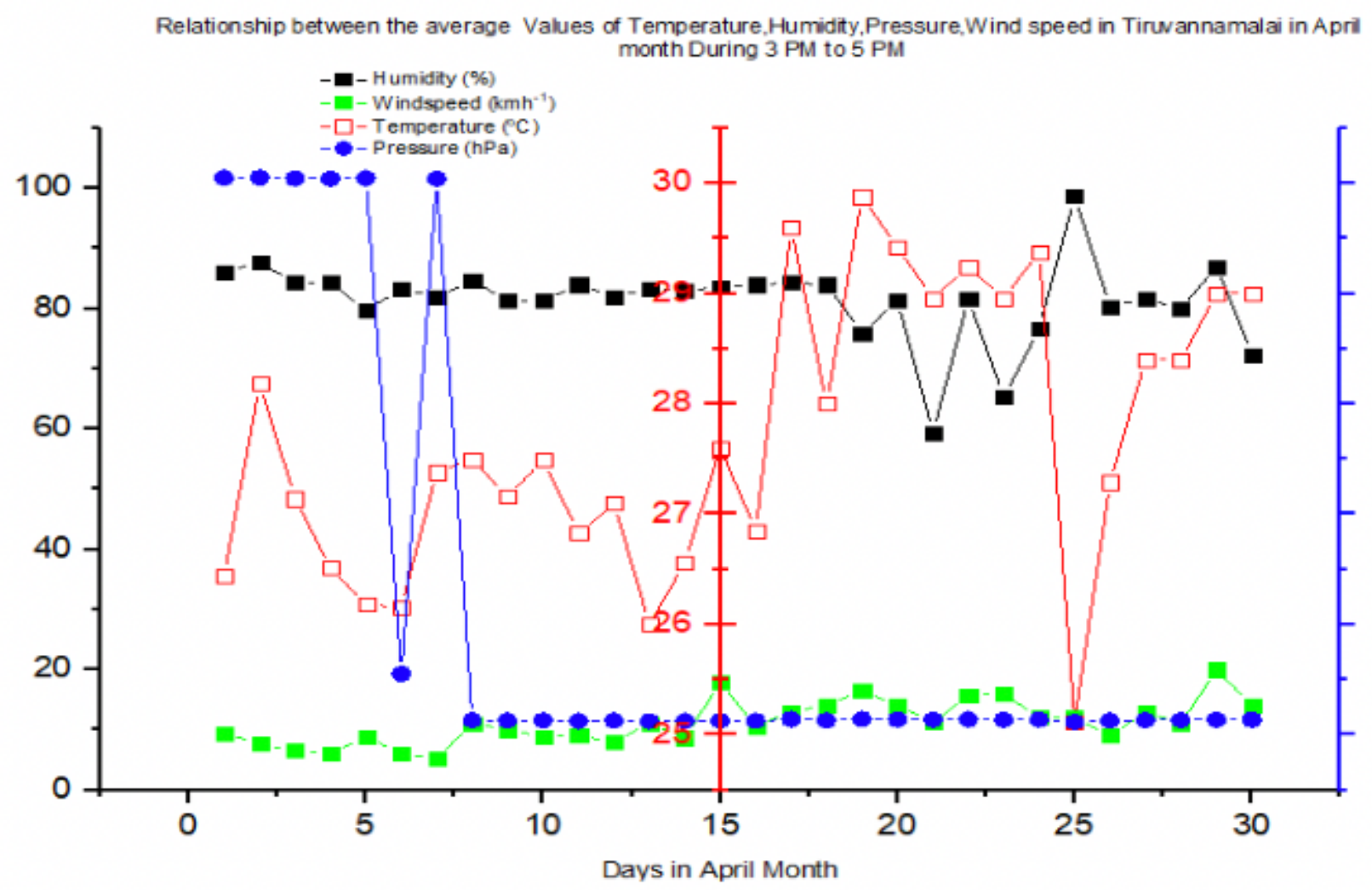

Figure 12

Relationship between the average values of temperature, humidity, pressure, wind speed in Tiruvannamalai during April month from 3pm to 6pm 


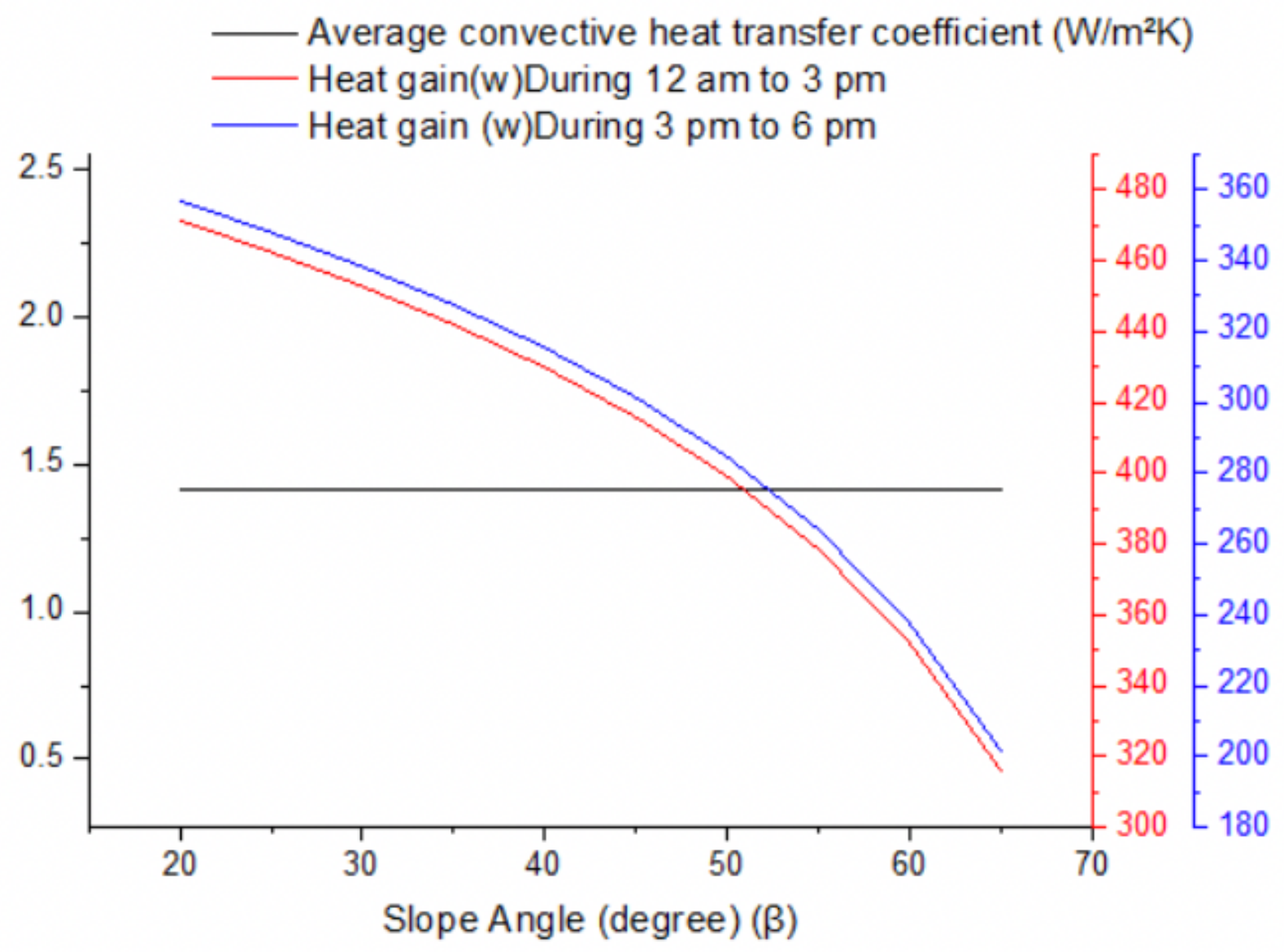

Figure 13

Average heat gain in moringa leaves during 12 am to $3 \mathrm{pm}$ and $3 \mathrm{pm}$ to $6 \mathrm{pm}$ 


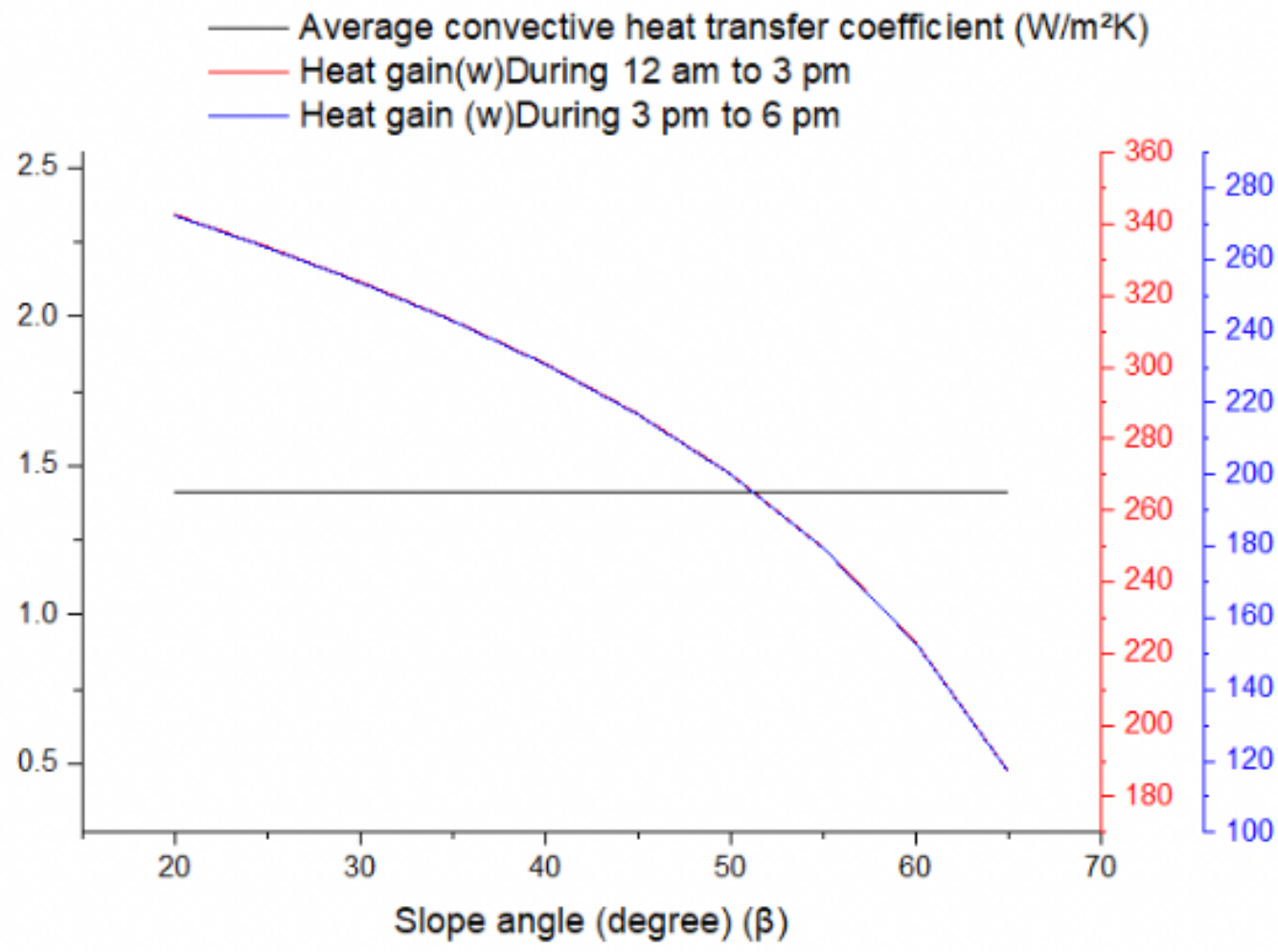

Figure 14

Average heat gain in neem leaves during 12 am to $3 \mathrm{pm}$ and $3 \mathrm{pm}$ to $6 \mathrm{pm}$ 


\section{Moisture Removal Rate(\%) of Neem Leaves in Solar Green House Dryer in Time periods}

9 AM to 12 Pm, 12 AM TO 3 PM AND 3 PM TO 6 PIM

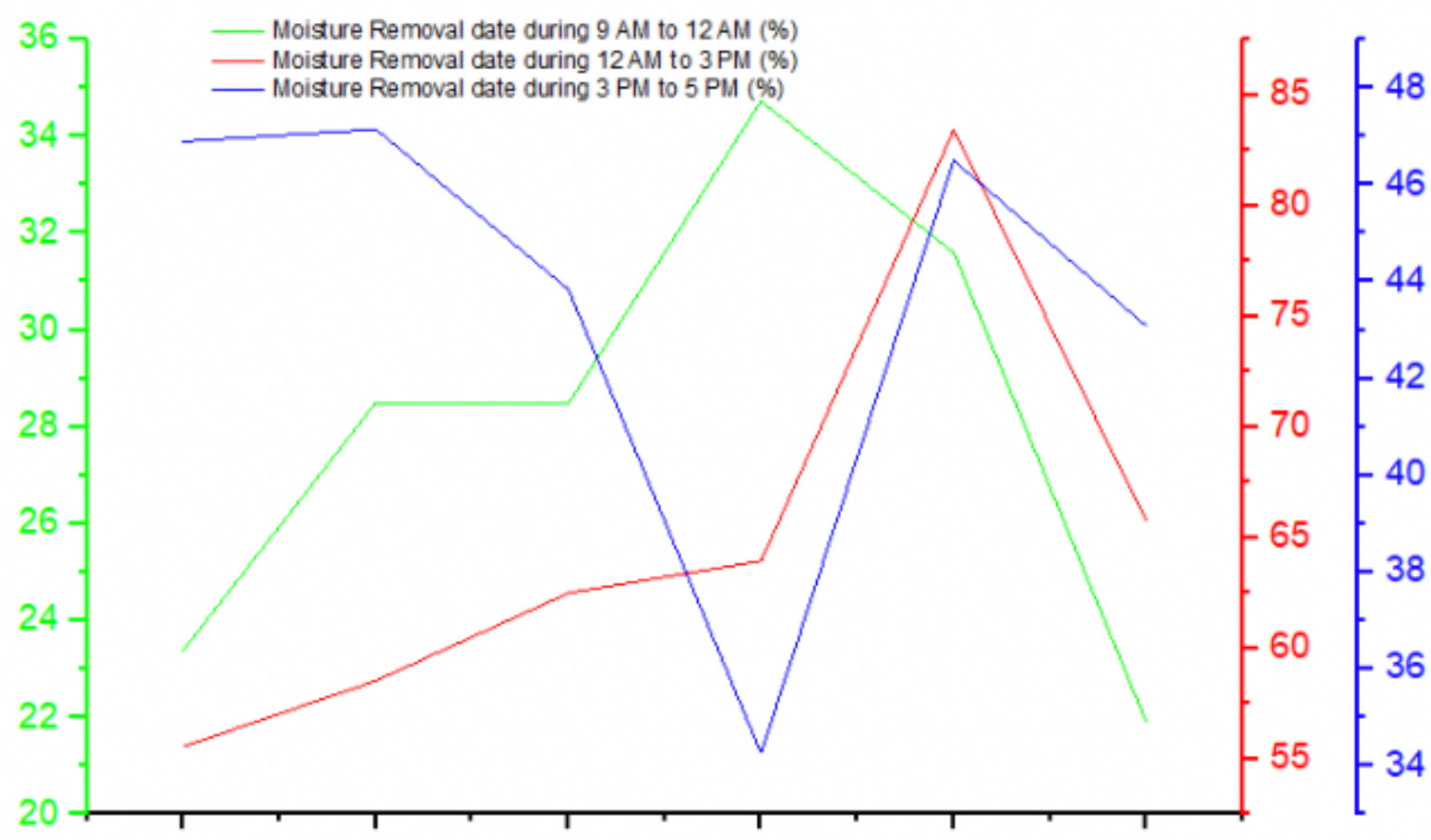

day $1(11 / 4)$ day $2(12 / 4)$ day $3(14 / 4)$ day $4(16 / 4)$ day $5(17 / 4)$ day $6(18 / 4)$

Days

\section{Figure 15}

Moisture removal rate of neem leaves during the clock hours 9 am to 12 am,12 am to $3 p m$ and $3 p m$ to $6 \mathrm{pm}$ 


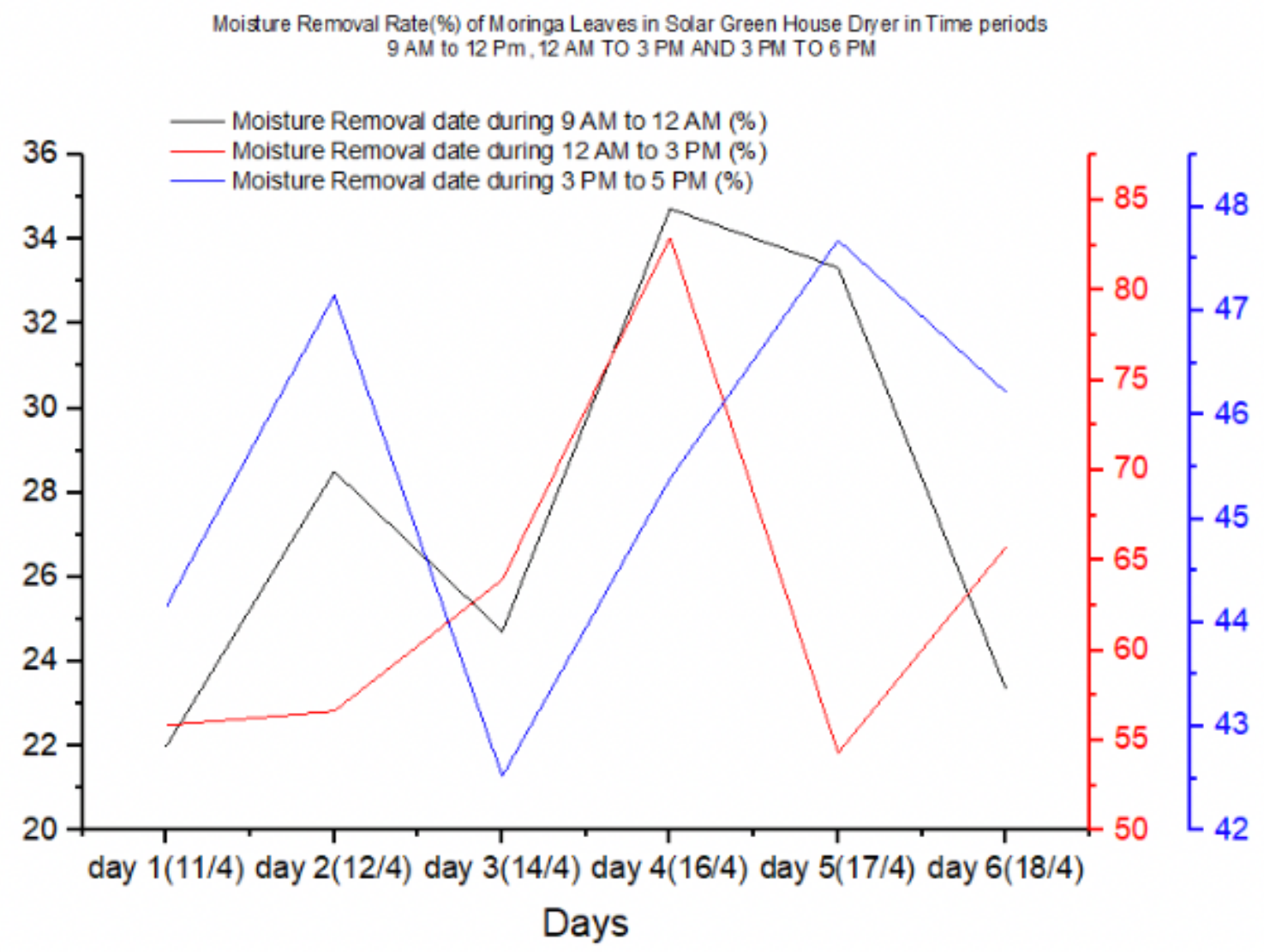

Figure 16

Moisture removal rate of moringa leaves during the clock hours $9 \mathrm{am}$ to $12 \mathrm{am}, 12$ am to $3 \mathrm{pm}$ and $3 \mathrm{pm}$ to $6 \mathrm{pm}$ 